\title{
47. LITHOSTRATIGRAPHY OF DEEP SEA DRILLING PROJECT LEG 90 DRILL SITES IN THE SOUTHWEST PACIFIC: AN OVERVIEW 1
}

\author{
Campbell S. Nelson, Department of Earth Sciences, University of Waikato ${ }^{2}$
}

\begin{abstract}
Leg 90 recovered approximately $3705 \mathrm{~m}$ of core at eight sites lying at middle bathyal depths (1000-2200 m) (Sites 587 to 594) in a traverse from subtropical to subantarctic latitudes in the southwest Pacific region, chiefly on Lord Howe Rise in the Tasman Sea. This chapter summarizes some preliminary lithostratigraphic results of the leg and includes data from Site 586, drilled during DSDP Leg 89 on the Ontong-Java Plateau that forms the northern equatorial point of the latitudinal traverse.

The lithofacies consist almost exclusively of continuous sections of very pure $\left(>95 \% \mathrm{CaCO}_{3}\right)$ pelagic calcareous sediment, typically foraminifer-bearing nannofossil ooze (or chalk) and nannofossil ooze (or chalk), which is mainly of Neogene age but extends back into the Eocene at Sites 588, 592, and 593. Only at Site 594 off southeastern New Zealand is there local development of hemipelagic sediments and several late Neogene unconformities. Increased contents of foraminifers in Leg 90 sediments, notably in the Quaternary interval, correspond to periods of enhanced winnowing by bottom currents. Significant changes in the rates of sediment accumulation and in the character and intensity of sediment bioturbation within and between sites probably reflect changes in calcareous biogenic productivity as a result of fundamental paleoceanographic events in the region during the Neogene.

Burial lithification is expressed by a decrease in sediment porosity from about 70 to $45 \%$ with depth. Concomitantly, microfossil preservation slowly deteriorates as a result of selective dissolution or recrystallization of some skeletons and the progressive appearance of secondary calcite overgrowths, first about discoasters and sphenoliths, and ultimately on portions of coccoliths. The ooze/chalk transition occurs at about $270 \mathrm{~m}$ sub-bottom depth at each of the northern sites (Sites 586 to 592) but is delayed until about twice this depth at the two southern sites (Sites 593 and 594). A possible explanation for this difference between geographic areas is the paucity of discoasters and sphenoliths at the southern sites; these nannofossil elements provide ideal nucleation sites for calcite overgrowths. Toward the bottom of some holes, dissolution seams and flasers appear in recrystallized chalks.

The very minor terrigenous fraction of the sediment consists of silt- through clay-sized quartz, feldspar, mica, and clay minerals (smectite, illite, kaolinite, and chlorite), supplied as eolian dust from the Australian continent and by wind and ocean currents from erosion on South Island, New Zealand. Changes in the mass accumulation rates of terrigenous sediment and in clay mineral assemblages through time are related to various external controls, such as the continued northward drift of the Indo-Australian Plate, the development of Antarctic ice sheets, the increased desertification of the Australian continent after 14 m.y. ago, and the progressive increase in tectonic relief of New Zealand through the late Cenozoic.

Disseminated glass shards and (altered) tephra layers occur in Leg 90 cores. They were derived from major silicic eruptions in North Island, New Zealand, and from basic to intermediate explosive volcanism along the Melanesian island chains. The tephrostratigraphic record suggests episodes of increased volcanicity in the southwest Pacific centered near 17, 13, 10, 5 and $1 \mathrm{~m} . y$. ago, especially in the middle and early late Miocene. In addition, submarine basaltic volcanism was widespread in the southeast Tasman Sea around the Eocene/Oligocene boundary, possibly related to the propagation of the Southeast Indian Ridge through western New Zealand as a continental rift system.
\end{abstract}

\section{INTRODUCTION}

This chapter highlights the general lithologic nature of Leg 90 deposits and also briefly comments on some other more specific items of lithologic interest in the cores. The intention has been to collate and summarize much of the lithostratigraphic information contained in several of the site chapters and specialist reports in this volume. A detailed discussion of specific topics has been avoided but $I$ hope that there is sufficient information to direct the interested reader to relevant chapters and core materials.

Leg 90 is one of several complementary DSDP legs organized to study global paleoceanographic changes during the Cenozoic. Previous rotary drilling during DSDP

\footnotetext{
${ }^{1}$ Kennett, J. P., von der Borch, C. C., et al., Init. Repts. DSDP, 90: Washington (U.S.

2 Printing Office).
Address: Dept. of Earth Sciences, University of Waikato, Private Bag, Hamilton, New

2 Address: Dept. of Earth Sciences, University of Waikato, Private Bag, Hamilton, New Zealand.
}

Legs 21 and 29 (Burns, Andrews, et al., 1973; Kennett, Houtz, et al., 1975) demonstrated that the southwest Pacific region is optimal for the study of thick, relatively uncomplicated, and continuously deposited pelagic carbonate sequences of Neogene age between the equator and the subantarctic. Unlike in most other oceanic regions, shallow-water platforms extend latitudinally over vast distances, providing an opportunity for drilling into oceanic pelagic sediments at relatively shallow depths.

With this background as basis, DSDP Leg 90 successfully obtained a traverse of middle to late Cenozoic sections between subequatorial and subantarctic water masses at eight sites (Sites 587 to 594) in the southwest Pacific region (Fig. 1). An additional site (Site 586) was for logistical reasons drilled on Leg 89; it is included in the Leg 90 Initial Report because it forms the northern equatorial point of the latitudinal traverse. Together these sites collected sediments beneath every major surface water mass between the tropics and the subantarctic, permitting paleoceanographic records to be analyzed for each 


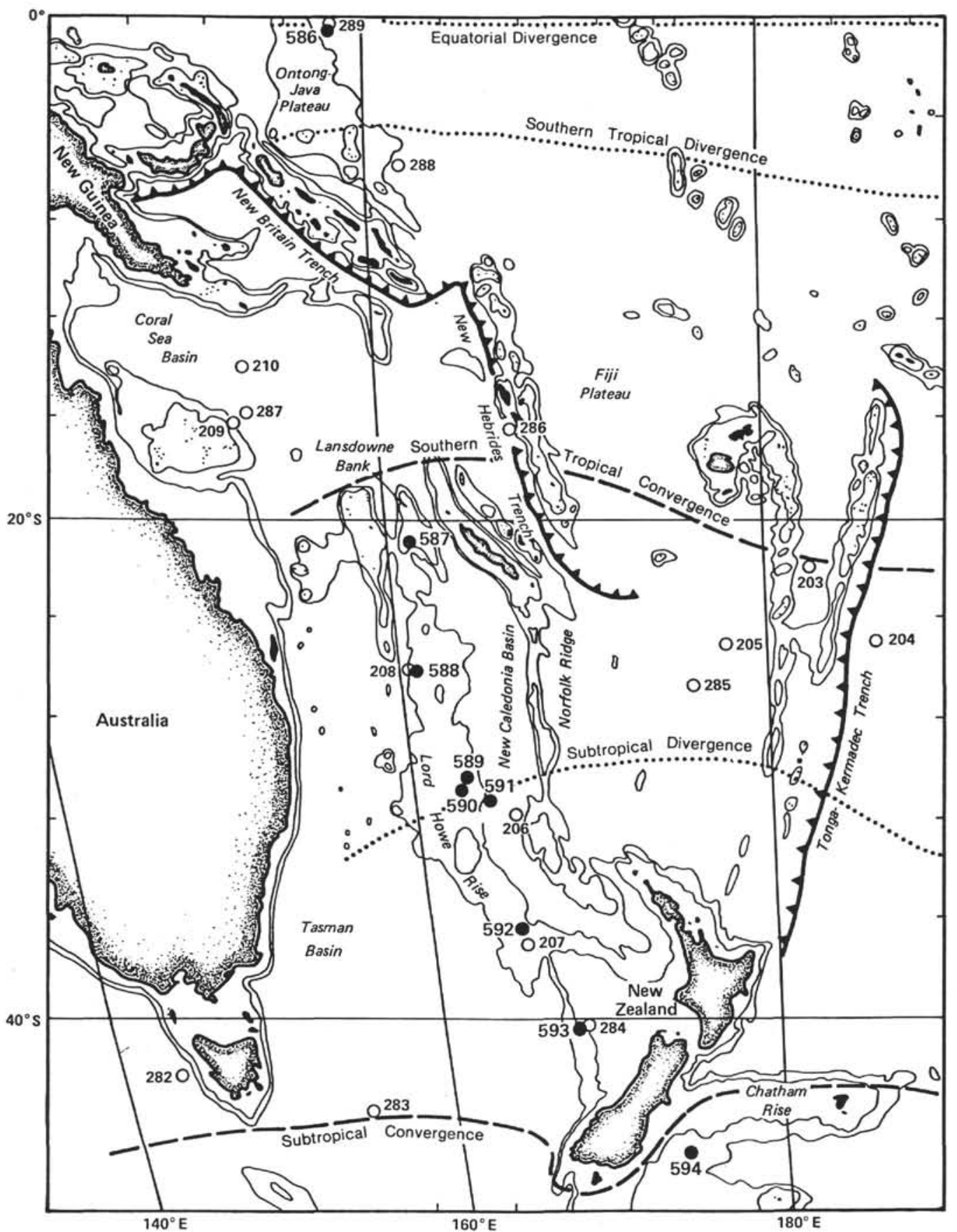

Figure 1. Location of Leg 90 drill sites (solid circles) and other DSDP sites (open circles) in the southwest Pacific region in relation to approximate positions of major surface water mass boundaries. Depth contours are for 1 and $2 \mathrm{~km}$.

water mass. In addition, this distribution of sites allows correlation of sections across a wide range of latitudes. A vertical traverse of sediment from water depths of $1299 \mathrm{~m}$ (Site 590), $2131 \mathrm{~m}$ (Site 591), and $3196 \mathrm{~m}$ (Site 206 of Leg 21) was also recovered at the mid latitudes.

Leg 90 recovered $3705 \mathrm{~m}$ of core, the longest for any drilling leg. Average core recovery for the entire leg was about $90 \%$ of the drilled section except for the Chatham Rise site (Site 594 ), where only about $65 \%$ core recovery was achieved. Some drill site statistics are summarized in Table 1 . Cores were obtained mainly with the hydrau- lic piston corer and extended core barrel systems (see introductory chapter, this volume), which provide sections of generally excellent quality with minimal core disturbance. The Leg 90 cores represent the most complete and coherent latitudinal traverse of Neogene sections from equator to subpole yet collected from the oceans.

All sites were drilled in middle bathyal water depths, from 1000 to $2200 \mathrm{~m}$ on submarine plateaus, which include Ontong-Java Plateau (Site 586) at the equator, Lord Howe Rise (Sites 587 to 592) and Challenger Plateau (Site 593) in the Tasman Sea, and southwestern 
Table 1. Summary of Leg 90 drilling.

\begin{tabular}{|c|c|c|c|c|c|c|c|c|}
\hline Hole & $\begin{array}{l}\text { Latitude } \\
\text { (S) }\end{array}$ & $\begin{array}{l}\text { Longitude } \\
\text { (E) }\end{array}$ & $\begin{array}{c}\text { Water } \\
\text { depth }(m)\end{array}$ & $\begin{array}{l}\text { Penetration } \\
\text { (m) }\end{array}$ & $\begin{array}{l}\text { No. of } \\
\text { cores }\end{array}$ & $\begin{array}{l}\text { Meters } \\
\text { cored }\end{array}$ & $\begin{array}{l}\text { Meters } \\
\text { recovered }\end{array}$ & $\begin{array}{l}\text { Percentage } \\
\text { recovered }\end{array}$ \\
\hline $586^{\mathrm{a}}$ & $00^{\circ} 29.84^{\prime}$ & $158^{\circ} 29.89^{\prime}$ & 2207 & 44.4 & 5 & 39.3 & 38.98 & 99.2 \\
\hline $586 \mathrm{~A}^{\mathrm{a}}$ & $00^{\circ} 29.84^{\prime}$ & $158^{\circ} 29.89^{\prime}$ & 2207 & 305.3 & 31 & 260.9 & 257.03 & 98.5 \\
\hline $586 \mathrm{~B}^{\mathrm{a}}$ & $00^{\circ} 29.84^{\prime}$ & $158^{\circ} 29.89^{\prime}$ & 2207 & 240.3 & 25 & 240.3 & 234.93 & 97.8 \\
\hline $586 \mathrm{C}^{\mathrm{a}}$ & $00^{\circ} 29.84^{\prime}$ & $158^{\circ} 29.89^{\prime}$ & 2207 & 623.1 & 1 & 9.6 & 2.18 & 22.7 \\
\hline 587 & $21^{\circ} 11.87^{\prime}$ & $161^{\circ} 19.99^{\prime}$ & 1101 & 147.0 & 17 & 147.0 & 88.81 & 60.4 \\
\hline 588 & $26^{\circ} 06.70^{\prime}$ & $161^{\circ} 13.6^{\prime}$ & 1533 & 236.0 & 26 & 236.0 & 220.76 & 93.5 \\
\hline $588 \mathrm{~A}$ & $26^{\circ} 06.70^{\prime}$ & $161^{\circ} 13.6^{\prime}$ & 1533 & 344.4 & 18 & 108.4 & 84.27 & 77.7 \\
\hline 588B & $26^{\circ} 06.70^{\prime}$ & $161^{\circ} 13.6^{\prime}$ & 1533 & 277.4 & 31 & 277.4 & 255.87 & 92.2 \\
\hline $588 \mathrm{C}$ & $26^{\circ} 06.70^{\prime}$ & $161^{\circ} 13.6^{\prime}$ & 1533 & 488.1 & 19 & 182.4 & 134.61 & 73.8 \\
\hline 589 & $30^{\circ} 42.72^{\prime}$ & $163^{\circ} 38.39^{\prime}$ & 1391 & 36.1 & 4 & 36.1 & 35.08 & 97.2 \\
\hline 590 & $31^{\circ} 10.02^{\prime}$ & $163^{\circ} 21.51^{\prime}$ & 1299 & 26.2 & 3 & 26.2 & 26.36 & 100.0 \\
\hline $590 \mathrm{~A}$ & $31^{\circ} 10.02^{\prime}$ & $163^{\circ} 21.51^{\prime}$ & 1299 & 280.8 & 27 & 254.6 & 224.17 & 88.0 \\
\hline $590 \mathrm{~B}$ & $31^{\circ} 10.02^{\prime}$ & $163^{\circ} 21.51^{\prime}$ & 1299 & 499.1 & 53 & 499.1 & 465.26 & 93.2 \\
\hline 591 & $31^{\circ} 35.06^{\prime}$ & $164^{\circ} 26.92^{\prime}$ & 2131 & 283.1 & 31 & 283.1 & 278.21 & 98.3 \\
\hline $591 \mathrm{~A}$ & $31^{\circ} 35.06^{\prime}$ & $164^{\circ} 26.92^{\prime}$ & 2131 & 284.6 & 30 & 284.6 & 233.15 & 81.9 \\
\hline $591 B$ & $31^{\circ} 35.06^{\prime}$ & $164^{\circ} 26.92^{\prime}$ & 2131 & 500.4 & 24 & 229.8 & 130.86 & 56.9 \\
\hline 592 & $36^{\circ} 28.40^{\prime}$ & $165^{\circ} 26.53^{\prime}$ & 1098 & 388.5 & 41 & 388.5 & 340.12 & 87.5 \\
\hline 593 & $40^{\circ} 30.47^{\prime}$ & $167^{\circ} 40.47^{\prime}$ & 1068 & 571.5 & 60 & 571.5 & 468.21 & 81.9 \\
\hline $593 \mathrm{~A}$ & $40^{\circ} 30.47^{\prime}$ & $167^{\circ} 40.47^{\prime}$ & 1068 & 496.8 & 27 & 257.3 & 227.71 & 88.5 \\
\hline 594 & $45^{\circ} 31.41^{\prime}$ & $174^{\circ} 56.88^{\prime}$ & 1204 & 505.1 & 53 & 505.1 & 299.72 & 59.3 \\
\hline $594 \mathrm{~A}$ & $45^{\circ} 31.41^{\prime}$ & $174^{\circ} 56.88^{\prime}$ & 1204 & 639.5 & 26 & 249.6 & 161.55 & 64.7 \\
\hline $594 \mathrm{~B}$ & $45^{\circ} 31.41^{\prime}$ & $174^{\circ} 56.88^{\prime}$ & 1204 & 42.9 & 5 & 42.9 & 34.18 & 79.6 \\
\hline
\end{tabular}

${ }^{\text {a }}$ For logistical reasons, Site 586 was cored on Leg 89.

Chatham Rise (Site 594) east of New Zealand. The sites lie well above the modern southwest Pacific lysocline depth of 2500 to $3500 \mathrm{~m}$ (Berger, 1976). Apart from Site 594 off southeastern New Zealand, the sediments are mainly free of turbidites and have received negligible inputs of terrigenous sediment.

\section{SITE LITHOSTRATIGRAPHIES}

\section{Stratigraphic Logs}

A variety of lithologic information for the nine drill sites in the southwest Pacific has been summarized on stratigraphic sections (Fig. 2). In addition to standard lithologic data, the figures include degree of sediment induration (soft, firm or stiff ooze, chalk, and recrystallized chalk); average sedimentation rates (m/m.y.) uncorrected for sediment porosity and calculated mainly from calcareous nannofossil zonal boundaries; the degree of sediment bioturbation; the state of preservation of planktonic foraminifers, benthic foraminifers, and calcareous nannoplankton and the relative abundance of pale green laminae representing altered tephra layers.

\section{Lithostratigraphic Subdivisions}

The lithostratigraphic succession at most sites is simple and they are broadly similar to one another (Figs. 2 and 3). The sections represent one correlatable lithostratigraphic unit that consists mainly of foraminifer-bearing nannofossil oozes (or chalks) and nannofossil oozes (or chalks) (Plates 1 and 2). This lithostratigraphic unit can be subdivided into as many as three subunits on the basis of color and degree of induration. The upper subunit is a thin ( 0.2 to $7.0 \mathrm{~m}$ thick) surficial zone of soft foraminifer-bearing or foraminifer-nannofossil ooze with a distinctive pale brown to orange color. The middle subunit is a thick ( 250 to $550 \mathrm{~m}$ ), soft to firm, light gray to white, foraminifer-bearing nannofossil ooze or nannofossil ooze. The lower subunit consists of light gray to white chalk, compositionally similar to the middle ooze subunit. Diagenesis controls the downcore distinction among these subunits, from the upper oxidized to the middle and lower reduced subunits, and from the weakly lithified ooze of the middle subunit to the more indurated chalk of the lower subunit. Repetition of these zones at Sites 592 and 593 makes it necessary to define additional subunits.

Other lithostratigraphic units were defined for Leg 90 sections but they are of only local significance. These minor lithostratigraphic units include siliceous chalks at the bottom of Site 592, a sequence of volcanogenic turbidites at the bottom of Site 593, and a thick (169 m) succession of alternations of hemipelagic and pelagic oozes at the top of Site 594.

\section{Unconformities}

Calcareous nannofossil and planktonic foraminiferal biostratigraphy at Sites 586 through 593, supported by diatom and radiolarian biostratigraphy at Site 594 , shows that all but two of the Neogene sections appear to be continuous (Fig. 3). Site 590 contains a 3 m.y. hiatus at the early/middle Miocene boundary. The section at Site 594 is interrupted by at least four unconformities, including a 2 m.y. gap in the middle late Miocene, and a $1 \mathrm{~m} . \mathrm{y}$. hiatus at the Miocene/Pliocene boundary, another between the early and late Pliocene, and another within the early Quaternary. None of these unconformities shows a lithologic expression.

Only three Leg 90 sites were drilled deep enough to potentially encounter the well-documented PaleogeneNeogene regional unconformity (Kennett et al., 1975). The unconformity was recovered at Sites 588 and 592, where it represents an hiatus of about 19 m.y. (from middle Eocene to late Oligocene) and 15 m.y. (from early Oligocene to late early Miocene), respectively. However, the unconformity is absent from Site 593 on Challenger Plateau, suggesting that the bottom currents that eroded 

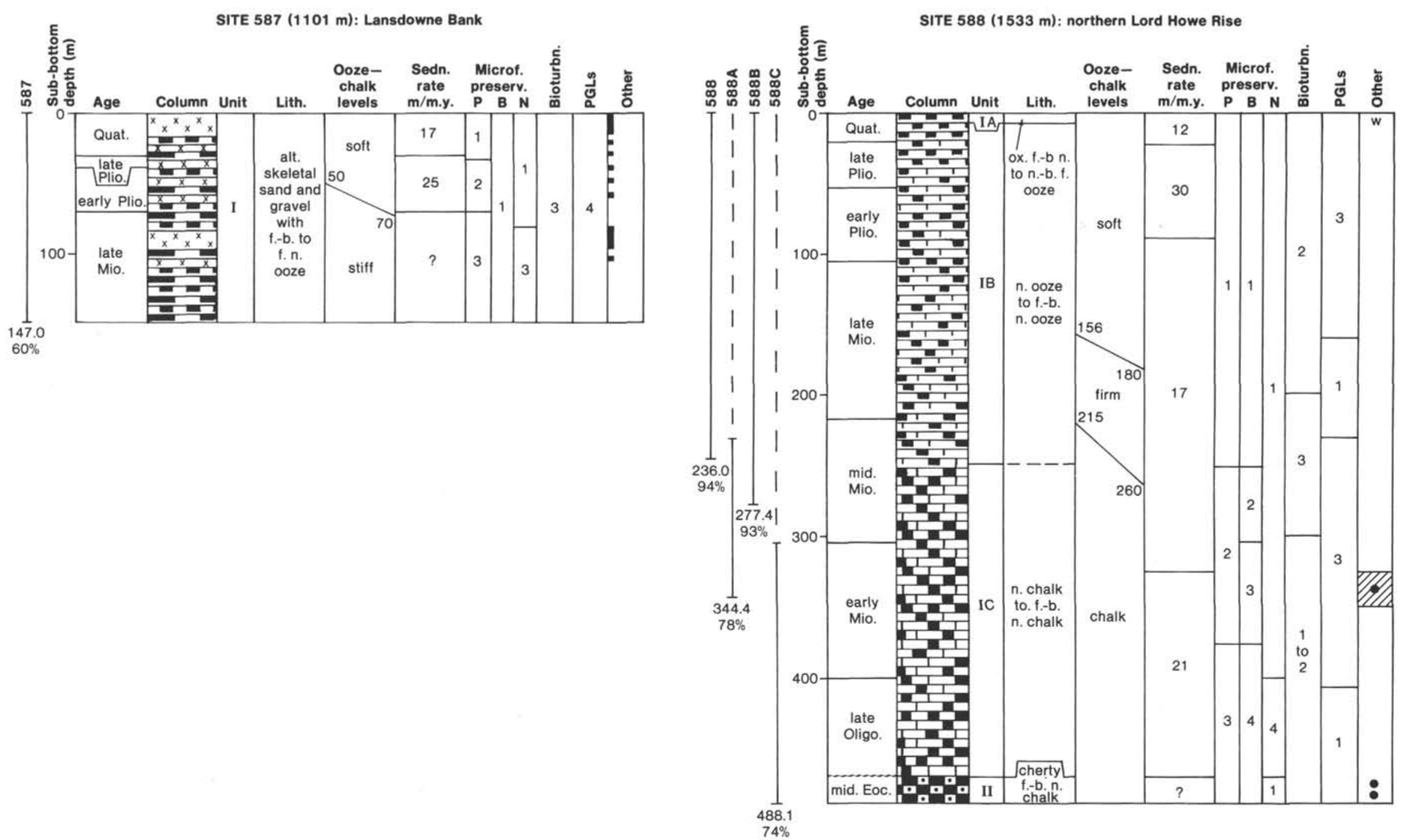

Figure 2. Summary stratigraphic logs for Leg 90 drill sites. 

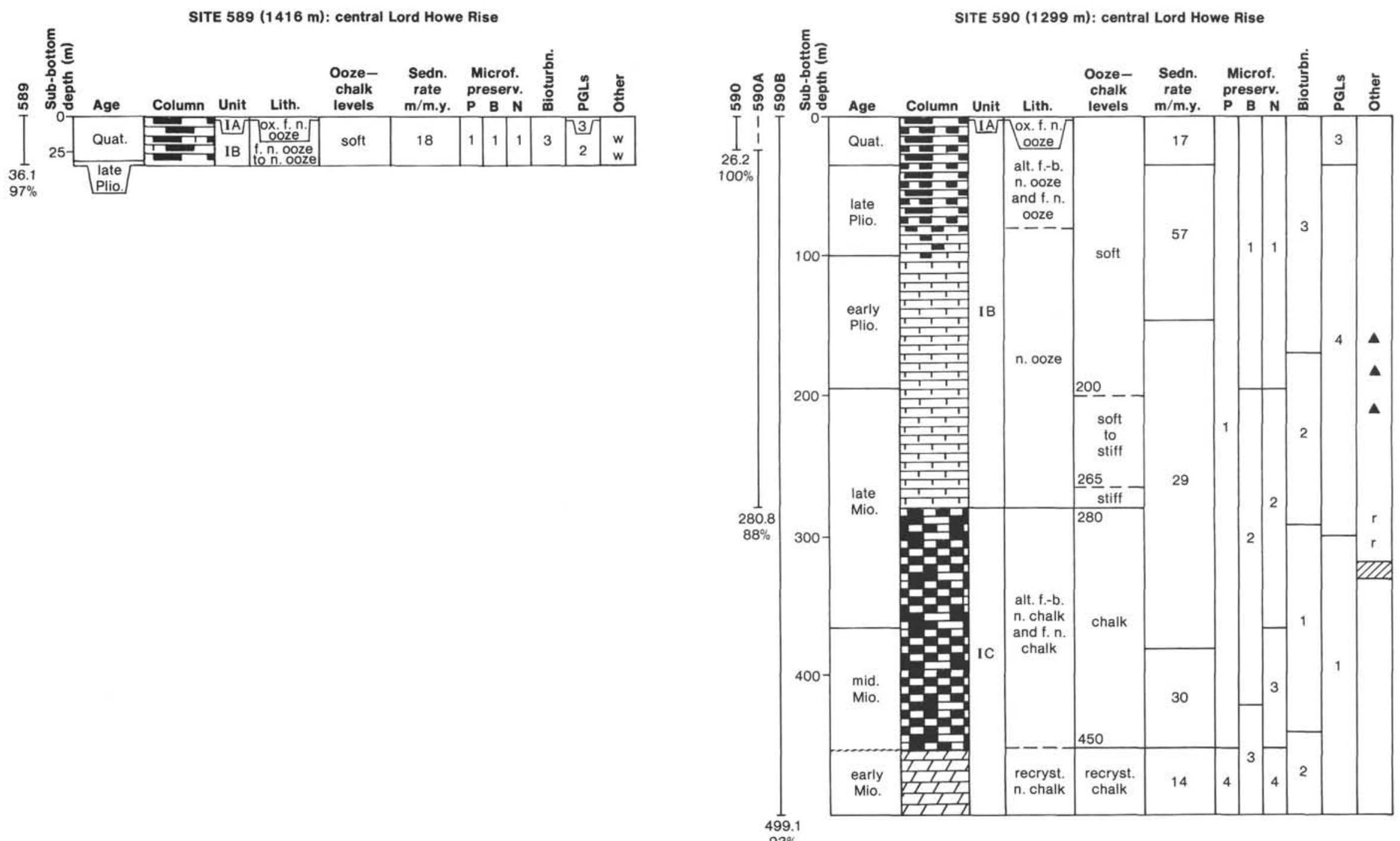

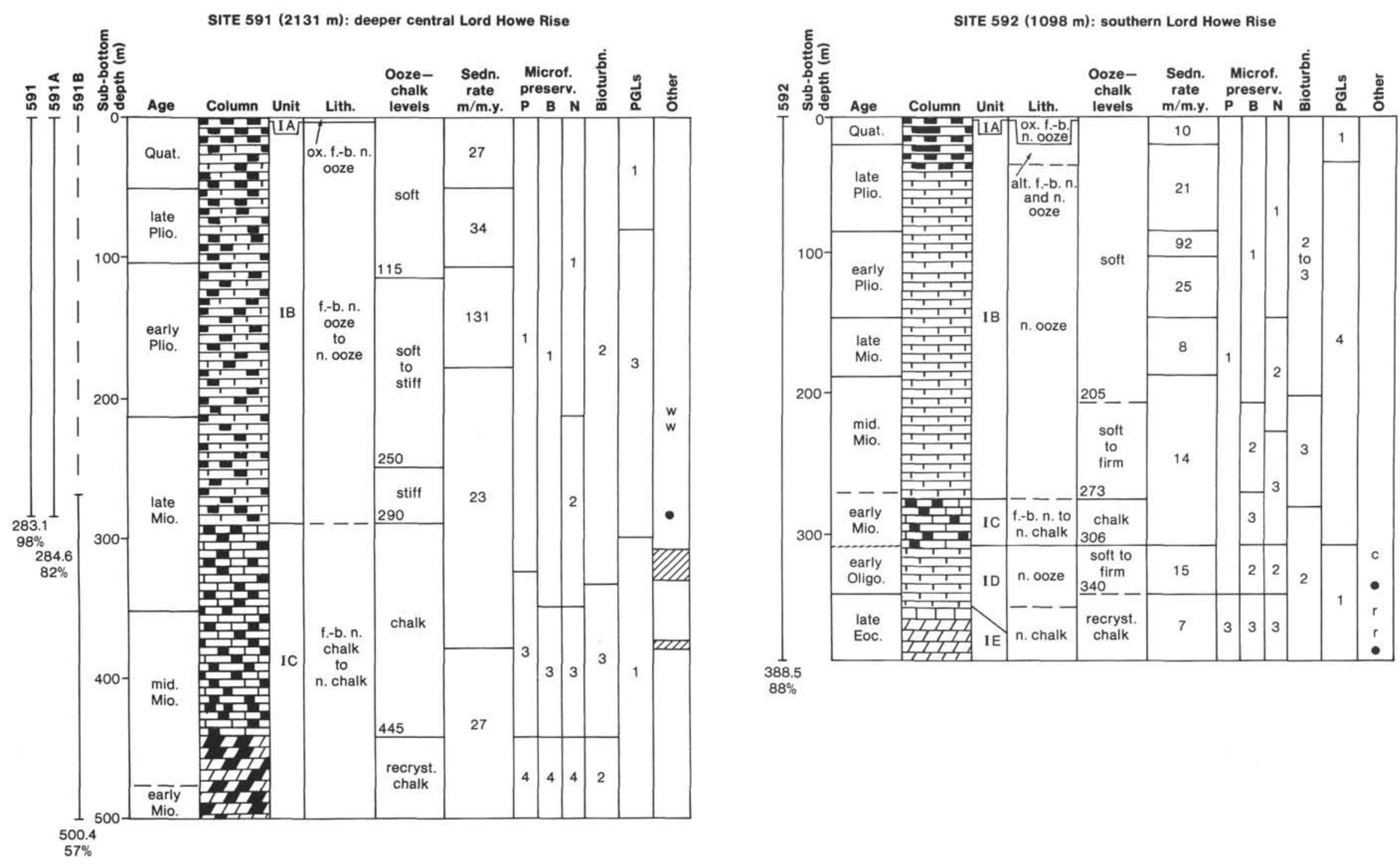


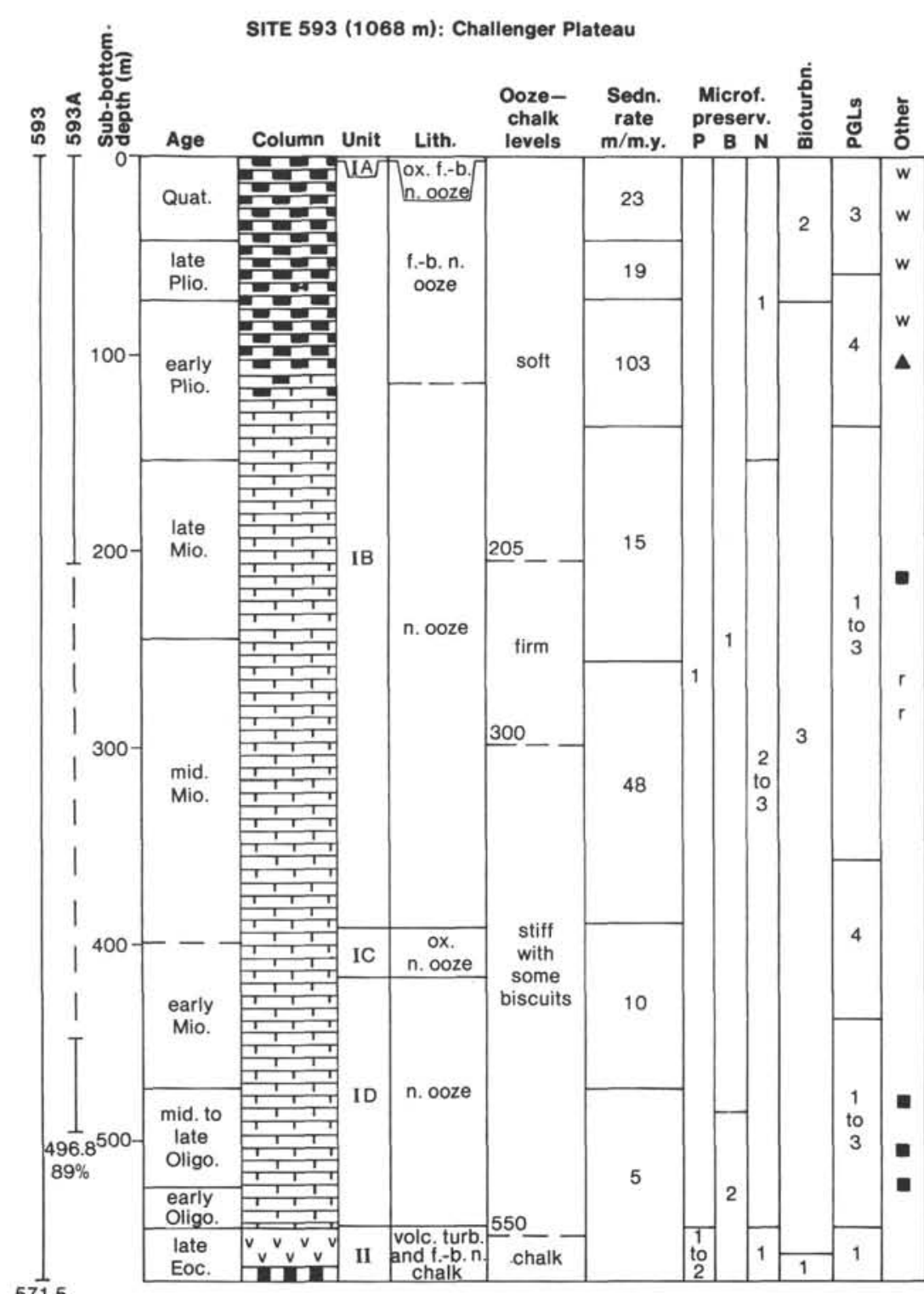

571.5
$82 \%$

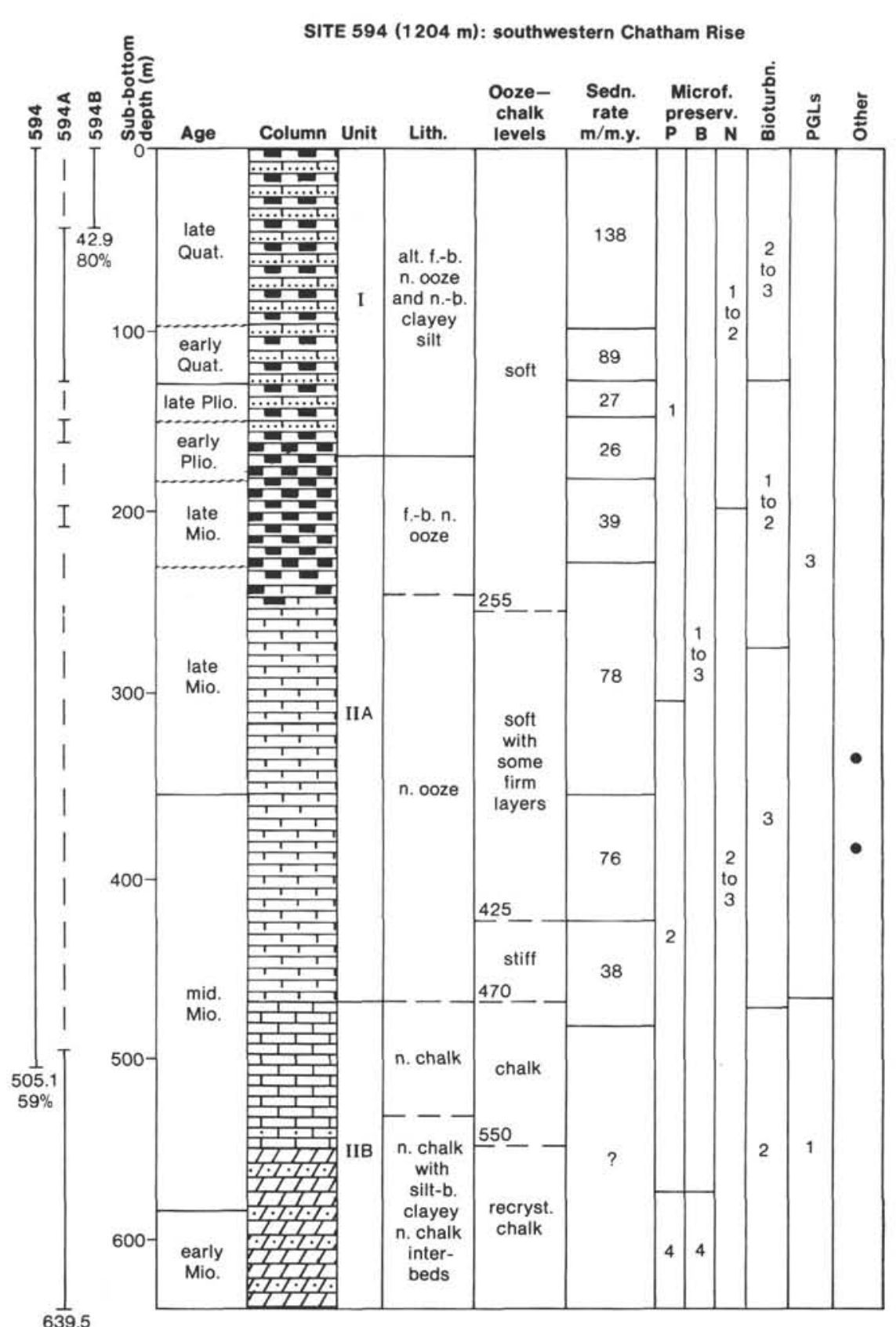

Figure 2. (Continued), 

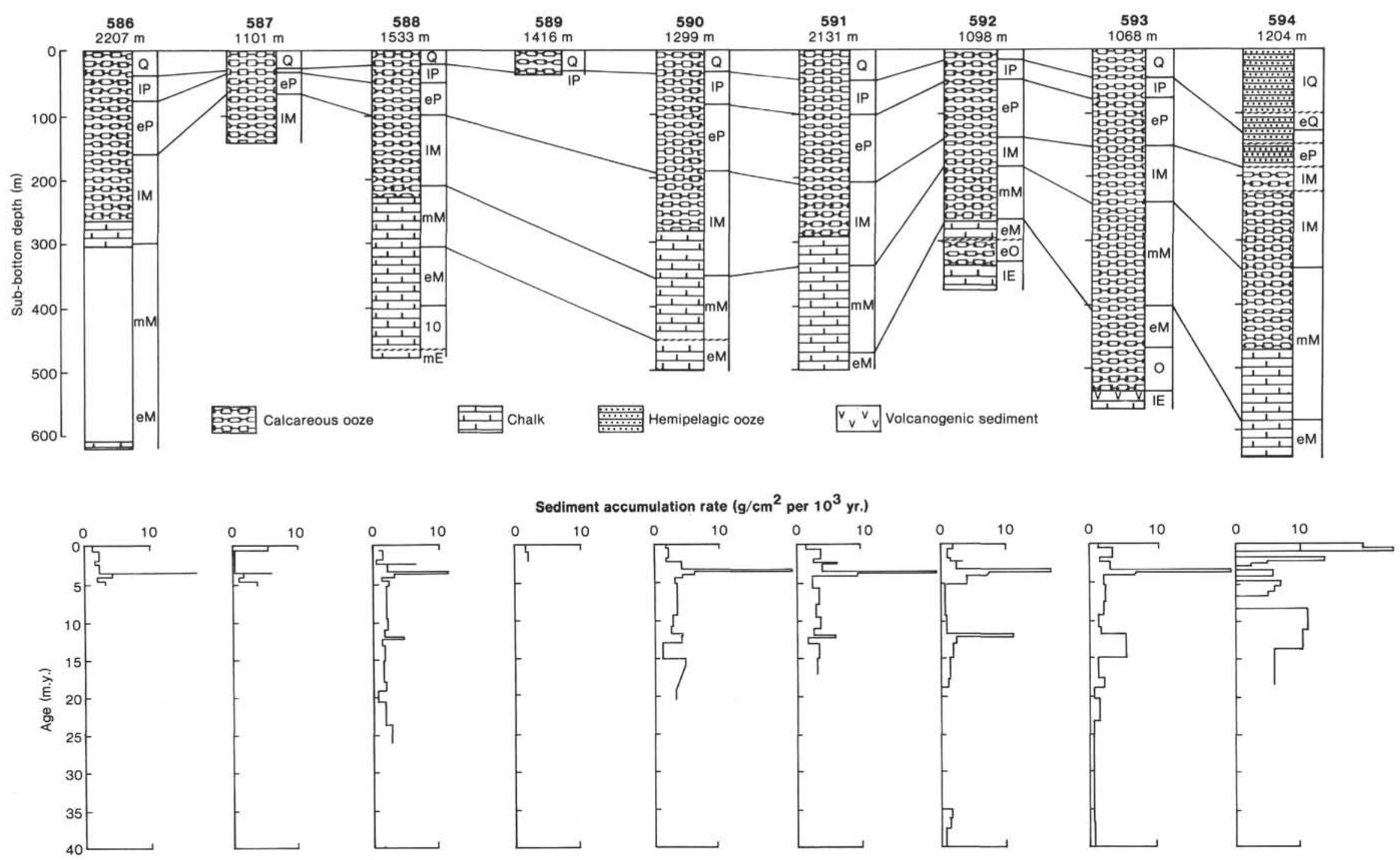

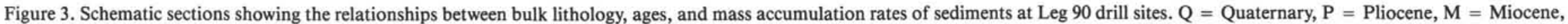
$\mathrm{O}=$ Oligocene, $\mathrm{E}=$ Eocene $\mathrm{l}=$ late, $\mathrm{m}=$ middle, $\mathrm{e}=$ early. 
the regional hiatus in Tasman Sea did not extend that far to the east.

\section{MAJOR LITHOLOGIES}

\section{Calcareous Oozes and Chalks}

Almost all sediment cored on Leg 90 is light-colored calcareous ooze or its more lithified equivalent, chalk (Table 2; Plates 1 and 2). Munsell sediment colors are typically white (N9), very light gray (N8), or light gray (N7), sometimes with subtle bluish (5B $7 / 1$ to $5 B$ 9/1) or greenish (5GY 7/1) tones. Skeletal material is completely dominated by calcareous nannofossils, with variable but small $(<5 \%)$ to moderate $(5-25 \%)$ quantities of foraminifers, so that the sediment is mainly nannofossil ooze (chalk) or foraminifer-bearing nannofossil ooze (chalk). Foraminifer-bearing nannofossil oozes (chalks) are more prevalent at the northern sites (Sites 586 to 591), and nannofossil oozes (chalks) prevail at the southern sites (Sites 592 to 594). Higher contents $(25-50 \%)$ of foraminifers occasionally occur and are associated with periods of intensified winnowing by bottom currents (Gardner, Dean, et al.; Stein and Robert; both this volume). Winnowing is especially evident in the Quaternary interval at several sites where alternating sequences of foraminifer and foraminifer-bearing nannofossil oozes are developed. Minor amounts of other calcareous microfossils, including dinoflagellates (calcispheres), ostracodes, and pteropods locally occur in the calcareous pelagic sediment.

The calcium carbonate contents of Leg 90 oozes and chalks range from about 90 to $98 \%$ (Gardner, Dean, et al.; Stein and Robert; both this volume). The small quantities of acid-insoluble material in the sediments are composed of terrigenous grains, some siliceous biogenic skeletons, and minor authigenic minerals. The terrigenous material includes quartz, feldspar, clay minerals, volcanic glass, mica, and very rare ferromagnesian minerals.

With the exception of some of the glass shards, which can range in size up to fine sand (Nelson, Froggatt, et al., this volume), the siliciclastic components are siltand clay-sized. The grain-size distribution of the siliciclastic silt remained very similar (modal size about $18 \mu \mathrm{m}$

Table 2. Percentage occurrence of different lithologies in sections drilled at Leg 90 sites.

\begin{tabular}{lccccc}
\hline Site & $\begin{array}{c}\text { Sub-bottom } \\
\text { depth } \\
(\mathrm{m})\end{array}$ & $\begin{array}{c}\text { Pelagic } \\
\text { calcareous } \\
\text { oozes }\end{array}$ & $\begin{array}{c}\text { Pelagic } \\
\text { chalks }\end{array}$ & $\begin{array}{c}\text { Hemipelagic } \\
\text { oozes }\end{array}$ & $\begin{array}{c}\text { Skeletal } \\
\text { sands and } \\
\text { gravels }\end{array}$ \\
\hline 586 & 305.3 & 92 & 8 & - & - \\
587 & 147.0 & 80 & - & - & - \\
$588^{\mathrm{a}}$ & 488.1 & 51 & 45 & - & - \\
589 & 36.1 & 100 & - & - & - \\
590 & 499.1 & 56 & 44 & - & - \\
591 & 500.4 & 58 & 42 & - & - \\
592 & 388.5 & 82 & 18 & - & - \\
$593^{\mathrm{b}}$ & 571.5 & 95 & 2 & - & - \\
$594^{\mathrm{c}}$ & 639.5 & 47 & 26 & 26 & - \\
\hline
\end{tabular}

${ }^{\text {a }}$ Sediments also include $4 \%$ siliceous chalks.

bediments also include $3 \%$ volcanogenic turbidites.

${ }^{c}$ Sediments also include $1 \%$ chalk turbidites. or medium silt) at all Lord Howe Rise silts throughout the Neogene. This silt, dominated by quartz and feldspar, was supplied mainly as eolian dust from the Australian continent (Stein and Robert, this volume). Distinct peaks in the mass accumulation rates of the terrigenous sediment occur in the middle Miocene (14 m.y.), latest Miocene (7-5 m.y.), and early Pliocene (4-3 m.y.) from Lord Howe Rise. These increases in mass accumulation rate are interpreted by Stein and Robert (this volume) to be the result of enhanced atmospheric circulation during maximum phases of aridity on the Australian continent, more or less coincident with major global cooling events. The terrigenous silt mode at Site 594 is commonly coarser (30-50 $\mu \mathrm{m})$ than on Lord Howe Rise because the site is close to New Zealand. The silt at Site 594 is dominated by chlorite, muscovite, and quartz, with lesser amounts of feldspar, reflecting the wide distribution of low-rank metamorphic rocks in South Island (Jarrett, 1985).

Trace quantities of volcanic shards are the most ubiquitous of all terrigenous components in Leg 90 sediments and may dominate the minor siliciclastic silt (to fine sand) fraction over thick sections of core (Gardner, Nelson, et al., this volume). Colorless shards dominate, but yellowish shards occur in several of the early Neogene sections, especially on northern Lord Howe Rise. It is likely that the shards were dispersed through the sediment by bioturbation. The tephras originated from explosive volcanic activity in North Island, New Zealand, and along the Melanesian island chains in the southwest Pacific (see section on tephras, later).

The siliciclastic clay fraction $(<2 \mu \mathrm{m})$ of Leg 90 sediments is dominated by clay minerals with some quartz, feldspar, and zeolites (Stein and Robert; Robert et al.; both this volume; Jarrett, 1985). Smectites are the most abundant clay minerals (typically $30-100 \%$ ), with illite $(0-45 \%)$, kaolinite $(0-35 \%)$, chlorite $(0-35 \%)$, and irregular mixed-layer clays (0-20\%) making up a smaller component. Despite some chemical modification during burial diagenesis, especially of smectite, the clays are primarily of detrital origin, transported by winds and ocean currents from Australia (Sites 587 to 593) and New Zealand (Sites 592 to 594) (Stein and Robert; Robert et al., this volume). The strong influence of a detrital supply of clays from New Zealand at southern sites is suggested by the occurrence of small amounts of stilpnomelane, a diagnostic accessory mineral in South Island schists. Stilpnomelane is found in sediment from the middle Miocene to Quaternary at Sites 593 and 594, and in Quaternary sediment at Site 592 (Robert et al., this volume).

At least three morphologic varieties of smectite occur in the sediments, suggesting it has different origins (Stein and Robert; Robert et al.; both this volume). Fleecy particles, of probable pedogenic detrital origin, are rare and restricted to the youngest cores. The dominant smectite variety occurs as very fine, delicate laths, sometimes grouped in distinctive geometric figures. The laths are only occasionally present in Quaternary and Pliocene ooze, but become especially abundant in Miocene and 
Paleogene sediment. The fine laths are interpreted by Stein and Robert (this volume) as having formed from the in situ recrystallization of (fleecy) detrital smectites in the sediment. It is also possible that a proportion of this smectite was neoformed in association with the selective dissolution of calcareous microfossil components during burial diagenesis, in the manner described by Marchig and Rösch (1983). The third smectite variety is thick laths or globular packs of fine laths that formed from the alteration of volcanic components. This volcanogenic smectite is most evident in sediment that is relatively enriched in glass shards or that contains greenish gray laminae of devitrified volcanic ash (see section on tephras, later).

Variations in the relative proportions of the different clay mineral species through time are related by Stein and Robert and Robert et al. (both this volume) to important changes in the locations and relief of landmasses, as well as to climatic conditions and patterns of ocean circulation. For example, at Sites 588 to 591 on northern Lord Howe Rise, the gradual increases in the content of illite and kaolinite at the expense of smectite in sediment younger than middle Miocene $(\sim 14 \mathrm{~m}$.y.) resulted from the onset and southward expansion of desertification in Australia, together with the continued northward drift of that continent into more tropical latitudes. At Sites 592 to 594 , nearer to New Zealand, the sudden and progressive increase of illite and chlorite at the expense of smectite after the end of the Oligocene occurred at the same time that the boundary between the Indo-Australian and Pacific plates in its present form (the Alpine Fault Zone) propagated through New Zealand and generated significant topographic relief. Moreover, the evolution from a predominantly oblique strike-slip boundary to an increasingly compressive one from the late Miocene onwards (the Kaikoura Orogeny) coincided with the period when smectite rapidly disappeared from the clay mineral record. The clay mineral evolution with time is very similar to that recorded by Nelson and Hume (1977) from New Zealand Cenozoic sequences on land.

Biosiliceous material is typically rare or absent in Leg 90 sediments. Biogenic components consist of radiolarians, sponge spicules, diatoms, silicoflagellates, and ebridians. Small amounts of siliceous microfossils persist throughout the sections at subantarctic Site 594 and the two deeper-water sites (Sites 586 and 591). The scarcity of biosiliceous material in Neogene sediments at all other Lord Howe Rise sites is surprising considering the relatively fast sediment accumulation rates, which suggest high productivity. The lack of siliceous biogenic components may be the result of postdepositional dissolution of opaline silica at the sea bed, possibly associated with the impingement of silica-undersaturated Antarctic Intermediate Waters onto the Rise (Gardner, Nelson, et al., this volume). The more consistent occurrence of siliceous microfossils in the Paleogene chalks on Lord Howe Rise (see also Burns, Andrews et al., 1973) suggests that an equivalent intermediate water mass was not developed at that time.

\section{Hemipelagic Oozes}

Because Site 594 is close to the South Island of New Zealand, sedimentation at the site has been influenced by both oceanic and terrigenous processes (Table 2 ). In particular, the topmost $169 \mathrm{~m}$ of Pliocene and Quaternary ooze includes a significant amount of silt- and claysized terrigenous material, dominantly chlorite, quartz, muscovite, feldspar, and illite, delivered to the site by prevailing westerly winds and ocean currents from the uplifted schist-dominated mountain chains of South Island (Griggs et al., 1983; Jarrett, 1985; Nelson, Hendy, Cuthbertson, et al., this volume). In detail, this section contains many fluctuations of hemipelagic and impure pelagic lithofacies that are evident from color changes in the core and calcium carbonate stratigraphy (Fig. 4; Nelson, Hendy, Cuthbertson, et al., this volume). The hemipelagic sediments are typically greenish gray $(5 \mathrm{G} 6 / 1)$ nannofossil-bearing clayey silts, rich in mica and quartz, often having diatoms and sponge spicules (Plate 1, Fig. 2). The $\mathrm{CaCO}_{3}$ contents in the hemipelagic sediments range from 0 to $25 \%$. In contrast, the pelagic interbeds are mainly bluish gray (5B 7/1) foraminifer-bearing nannofossil oozes with reduced but variable amounts of terrigenous material and only trace quantities of biosiliceous components. The $\mathrm{CaCO}_{3}$ contents of these sediments range between 50 and $80 \%$. Oxygen isotope analyses (Fig. 4; Nelson, Hendy, Cuthbertson, et al., this volume) confirm that the hemipelagic sediment accumulated during lowered eustatic sea level of glacial periods and that the impure pelagic sediment was deposited during times of high eustatic sea level of interglacial periods. The history of alpine glaciations and associated erosion in South Island, represented by the hemipelagic oozes, can be correlated via isotope stages with the major fluctuations of Northern Hemisphere ice sheets (e.g., Imbrie et al., 1985). The existence of strong 100,41 , and $23 \times 10^{3} \mathrm{yr}$. (Milankovitch) cycles in the carbonate and isotope records of this high-accumulation section (Nelson et al., 1984) makes it valuable for very detailed study of late Quaternary climate changes.

\section{MINOR LITHOLOGIES}

\section{Skeletal Sands and Gravels}

At least $20 \%$ of the recovered section at Site 587 on Lansdowne Bank, northernmost Lord Howe Rise, consists of yellowish to pinkish gray coarse-grained skeletal carbonate debris with silty sand, sand, sandy gravel, or gravel textures. These sediments occur in massive or normally graded beds, less than 1 to $2 \mathrm{~m}$ thick, that alternate with a dominant lithofacies of foraminifer (-bearing) nannofossil ooze. Many of the sediment components in the coarse interbeds are of shallow-marine origin and include broken and/or abraded tests of large benthic foraminifers, fragments of calcareous red and green algae (including Halimeda), corals, bryozoans, and echinoderm material, and carbonate lithoclasts of chalk and skeletal packstone and wackestone. They represent re- 

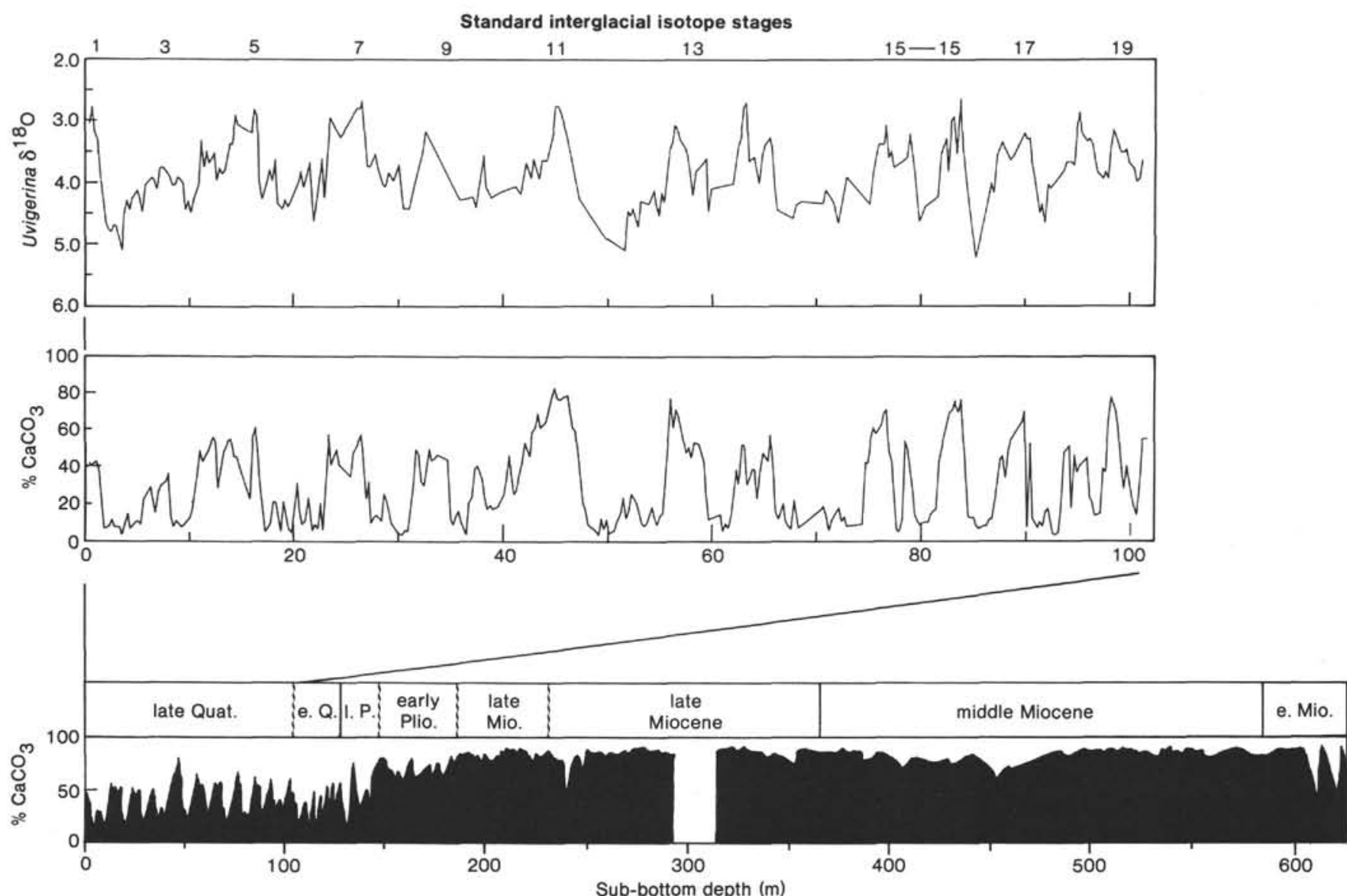

Figure 4. Calcium carbonate stratigraphy at Site 594, southeastern New Zealand (from Jarrett, 1985), including high-resolution carbonate and benthic foraminiferal (Uvigerina sp.) oxygen isotope stratigraphies for the top $100 \mathrm{~m}$ of section (from Nelson, Hendy, et al., this volume). Note that (1) the calcareous oozes and chalks are generally less pure (80-90\%) than most other Leg 90 calcareous sediments because the site is close to New Zealand (increased terrigenous content) and in subantarctic waters (increased biosiliceous material); (2) fluctuating $\mathrm{CaCO}_{3}$ values in the late early Miocene are due to interbeds of impure chalk turbidites; (3) the overall decrease in $\mathrm{CaCO}_{3}$ content after the latest Miocene ( $\sim 6 \mathrm{~m}$.y.) corresponds to the Kaikoura Orogeny, with progressive elevation of the New Zealand Southern Alps along the Alpine Fault zone; (4) the drop in CaCO $\mathrm{Con}_{3}$ tent in the late Pliocene ( $\sim 3$ m.y.) may correlate with the oldest known late Cenozoic glacial sediments (the Ross glacial deposits) on South Island and the onset of the Northern Hemisphere Ice Age; and (5) the cyclic alternations of high-carbonate impure pelagic oozes and low-carbonate hemipelagic oozes in the late Quaternary correspond to fluctuating interglacial and glacial episodes, respectively, indicated by the isotope record. Standard interglacial isotope stages tentatively identified on the isotope record are discussed by Nelson, Hendy, et al. (this volume).

worked and redeposited sediment derived from the photic zone of nearby banks and transported downslope, possibly during low stands of sea level. Surficial and buried channels are seen on the seismic profile near Site 587.

\section{Siliceous Chalks}

Siliceous sediment is extremely rare in Leg 90 cores, but isolated chert nodules were recovered from a few stratigraphic levels at Sites 588, 591, 592, and 594 (Fig. 2). The chalk from the bottom $19 \mathrm{~m}$ of Site 588 includes common siliceous material, mainly sponge spicules, diatoms, and diagenetic chert (Plate 2, Fig. 3), and the chalk at the base of Site 592 contains rare radiolarians and chert nodules. The cherty beds at Sites 588 and 592 are both Eocene and lie below the regional unconformity that represents a significant portion of the Paleogene succession. The siliceous lithologies and chronostratigraphies are identical to those recorded at Sites 206 to 210 , drilled in the Tasman and Coral seas on DSDP Leg
21 (Burns, Andrews, et al., 1973; van der Lingen et al., 1973).

\section{Chalk Turbidites}

Below about $534 \mathrm{~m}$ sub-bottom and continuing to the bottom $(640 \mathrm{~m})$ of the section at Site 594, the otherwise relatively pure nannofossil chalks of late early to early middle Miocene age include occasional conspicuous "chocolate-colored" (olive gray 5Y 4/1) interbeds of silt-bearing clayey nannofossil chalk that are sometimes sponge-spicule-bearing (Figs. 2 and 4). The terrigenous components of the interbeds are common mica and clay minerals (illite and smectite), some quartz, and feldspar. This mineralogy is broadly similar to the siliciclastic mineralogy of the Pliocene-Quaternary hemipelagic oozes at the top of the section. Individual interbeds have sharp erosional bases, range in thickness from a few to $90 \mathrm{~cm}$, and are normally graded from medium to very fine silty and eventually clay-dominated and bioturbated sediment which passes imperceptibly into overlying chalk con- 
taining reworked microfaunas. The sedimentary structures suggest that these impure chalk interbeds are turbidites. A pronounced habitat stratification of infaunal burrow types occurs in the upper portion of the thicker beds, with Planolites between 0 and about $5 \mathrm{~cm}$ down, Chondrites below to depths of $10 \mathrm{~cm}$, and Zoophycos to depths of 15 to $20 \mathrm{~cm}$ in the bed (Nelson, this volume, Plate 1, Figs. 11, 12), similar to that reported elsewhere for the burrowed tops of turbidite deposits (Seilacher, 1978).

The impure chalk turbidites may record an early Neogene phase of active fan progradation into the head of the Bounty Trough (Carter and Carter, 1984). Tectonic movements and erosion occurred on nearby South Island of New Zealand, so that periodically large volumes of fine terrigenous sediment were supplied to the area of Site 594.

\section{Volcanogenic Turbidites}

The only noncarbonate lithostratigraphic unit drilled on Leg 90 was a $16.4 \mathrm{~m}$ section of thinly bedded, grayish black (N2) to grayish green (10G 4/2), lithified volcanogenic sandstone, mudstone, and occasional breccia at the bottom of Site 593, Challenger Plateau, southern Tasman Sea (Nelson, Briggs, et al., this volume). The sequence was rapidly emplaced at bathyal depths at about the time of the Eocene/Oligocene boundary, 37 to 36 m.y. ago. Late Eocene nannofossil chalk occurs below, and early Oligocene nannofossil ooze is found above the volcanogenic unit. It comprises at least 35 sharp-based and normally graded volcanogenic sandstone-mudstone couplets or turbidites, each typically $20-50 \mathrm{~cm}$ thick and with common Bouma A, B, and E divisions. Rarer thick beds of massive or inversely graded, unsorted breccia were probably deposited from highly concentrated laminar suspensions resembling debris flows. The turbidites and debris flows almost certainly originated on the slopes of "Lalitha pinnacle," a now-buried volcanic shield 500 $\mathrm{m}$ high (av. 6-8 $8^{\circ}$ slopes), situated only a few kilometers from Site 593. A variety of evidence supports a basaltic origin for the sequence, but the basic glassy components that form the bulk of the deposits have been pervasively palagonitized and replaced by phillipsite, smectite, and calcite as a result of low-temperature oxidative alteration by pore fluids, presumably during early diagenesis. Seismic evidence indicates that buried volcanoes of similar character and age to "Lalitha pinnacle" are widespread on southern Lord Howe Rise and Challenger Plateau, suggesting a significant period of submarine basaltic volcanism in the southeast Tasman Sea region about 37 m.y. ago. Nelson, Briggs, et al. (this volume) view the volcanic activity as off-rift volcanism related to regional extension and formation of a major continental rift system through western New Zealand in the late Eocene-early Oligocene. These tectonic adjustments were the result of the eastward propagation of the Southeast Indian Ridge into the south Tasman Sea and through the New Zealand subcontinent. Analogous occurrences of submarine Eocene-Oligocene basalts east of the rift system now crop out on land in eastern South Island, New Zealand.

\section{Tephras}

\section{Megascopic Vitric Tephras}

Explosive volcanism has characterized large areas of the southwest Pacific region throughout the late Cenozoic (Churkin and Packham, 1973; Coleman and Packham, 1976) and so it is not surprising that glass shards are ubiquitous in the sediment at most sites drilled on Leg 90. The stratigraphic occurrence of glass shards in smear slides of sediments for five sites on Lord Howe Rise has been summarized by Gardner, Nelson, et al. (this volume). The shards typically occur in trace amounts $(<1 \%)$ only and are mainly dispersed through the sediment, probably by bioturbation of thin ash layers. Careful processing of channel samples from cores may ultimately provide a useful tephrostratigraphy based on the frequency distribution of this dispersed volcanic glass fraction.

Occasional discrete, $1-10 \mathrm{~cm}$ thick layers of glassdominated tephra occur in the cores. Eighteen of these megascopic tephras have been studied in detail by Nelson, Froggatt, et al. (this volume). The majority are silicic (75 to $\left.78 \% \mathrm{SiO}_{2}\right)$, with abundant clear glass shards and a biotite \pm hypersthene \pm green hornblende ferromagnesian mineralogy. The megascopic tephras were derived from Miocene through Quaternary eruptions in North Island, New Zealand. Several of the Quaternary silicic tephras can be correlated to one another, and at least two can be matched to the widespread on-land Mt. Curl tephra ( $\sim 0.25$ m.y. ago), with a probable source in Lake Taupo. The occurrence of North-Island-derived tephras in central and northern Lord Howe Rise sites suggests that ash normally transported eastward into the Pacific by the prevailing westerly airflow across New Zealand may also be diverted northwest and west on entering the Southeast Trade wind belt to be deposited ultimately in the Tasman Sea region. Moreover, the occurrence of correlative silicic tephras up to $3500 \mathrm{~km}$ apart at sites on northern Lord Howe Rise (Sites 588 to 591) and off eastern South Island (Site 594) is evidence of occasional exceptionally large eruptions. Nelson, Foggatt, et al. (this volume) have suggested that some ash in the eruptive column ascended above $20 \mathrm{~km}$ altitude and may have been directly carried toward the Tasman Sea by stratospheric winds, while coeval lower-level ash drifted east of New Zealand into the southern Pacific Ocean.

Only three of the megascopic tephras analyzed were nonsilicic. They occur in Neogene sediments at northern sites (Sites 586 to 588) and are composed of altered (partially devitrified and pyritized) basic shards and common labradorite crystals derived from explosive basaltic to andesitic volcanism at nearby ocean island or ridge sources, probably in the Ontong-Java Plateau and Vanuatu regions. Considering that basic to intermediate volcanic activity overwhelmingly preponderates in the southwest Pacific, notably along the volcanic island chains of the Melanesian Borderland at the boundary between the Indo-Australian and Pacific plates (Coleman and Packham, 1976), the apparent paucity of more basic tephras in Leg 90 sediments appears at first to be anomalous. The situation may be explainable by the occurrence of pale green layers in the sediments. 


\section{Pale Green Laminae}

During the shipboard descriptions of the calcareous oozes and chalks on Leg 90, numerous pale green laminations (PGLs) were noted to recur persistently throughout long intervals of many cores (Fig. 2). The laminae are isolated or occur in composite sets, are typically 0.5 to $2 \mathrm{~mm}$ thick, are horizontal or nearly so, and commonly are associated with underlying concentrations of iron sulfides. The stratigraphic distribution and origin of PGLs at Lord Howe Rise sites are discussed in detail by Gardner, Nelson, et al. (this volume) and their composite PGL stratigraphy is summarized here in Figure 5.

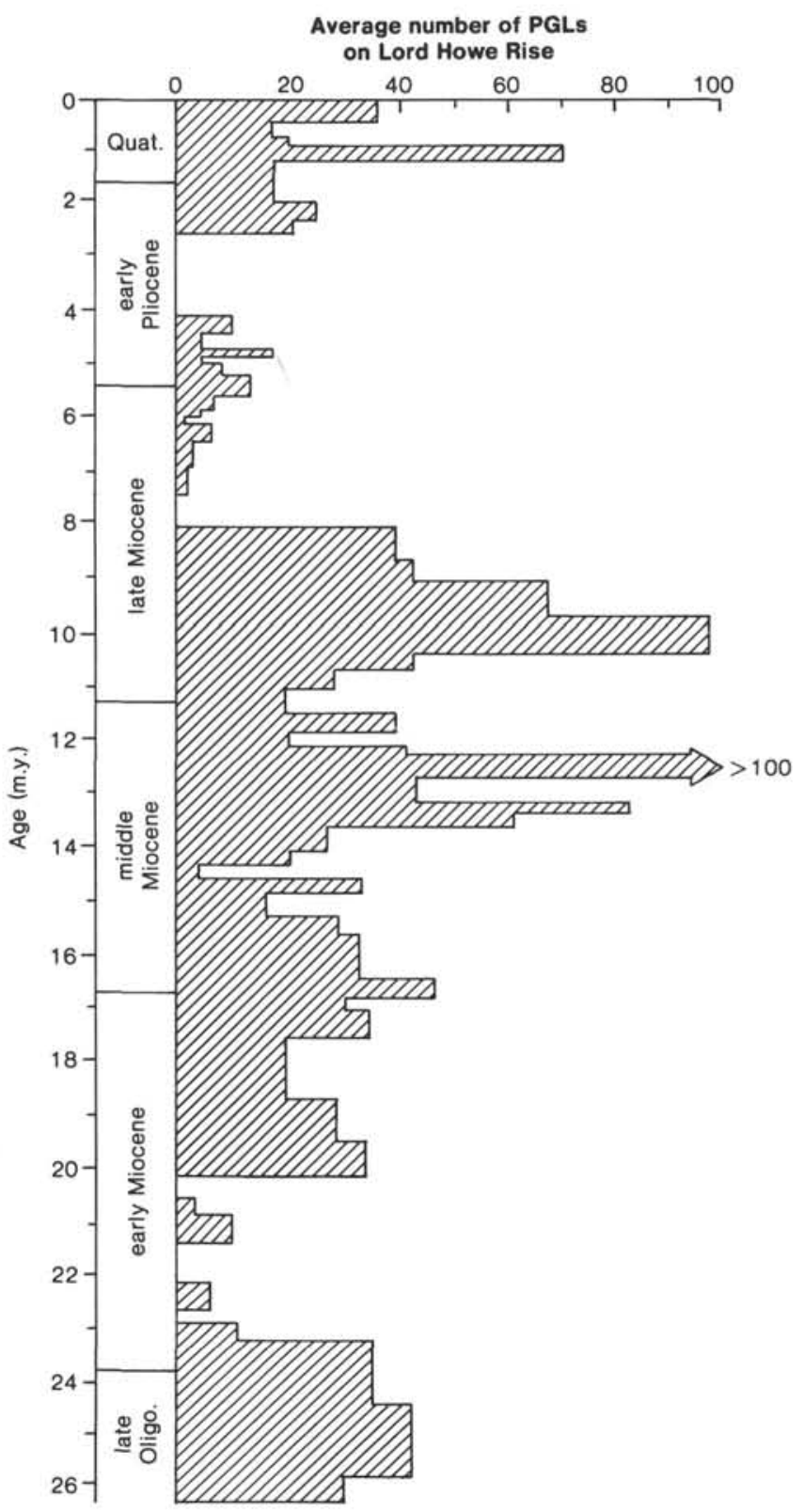

Figure 5. The overall distribution of pale green laminae (PGLs) interpreted as altered ash layers in Leg 90 drill sites on Lord Howe Rise (from Gardner, Nelson, et al., this volume). Note major episodes of explosive volcanism centered near 10 and 13 m.y. ago.
They argue that the PGLs represent diagenetically altered volcanic ash layers from regional volcanic events, principally on the basis that (1) the laminae are completely dominated by authigenic smectite and are therefore equivalent to bentonite layers; (2) because terrigenous components are absent in the sediment, the iron necessary for the formation of the associated iron sulfides could only be supplied by alteration of the overlying volcanic ash, the sulfur being supplied by sulfate reduction of pore water; and (3) the times at which the laminae occur closely match periods of reported volcanism from the southwest Pacific and circum-Pacific (Kennett et al., 1977). Volcanicity peaked in the latest early Miocene to early middle Miocene (18-15 m.y.), the late middle Miocene (14-12 m.y.), the early late Miocene (11$9 \mathrm{~m} . \mathrm{y}$.), and the latest Pliocene to Quaternary (3-0 m.y.). However, the PGL tephrostratigraphy of the region is considerably more complex and detailed than was previously known; in particular, it suggests that middle and early late Miocene volcanism was much more active in this sector of the southwest Pacific than it was during the Quaternary (cf. Kennett et al., 1977). A broad correlation is evident between maxima in the PGL record and periods of increased intensity of convergence at the boundary between the Indo-Australian and Pacific plates in the southwest Pacific (Gardner, Nelson, et al., this volume).

Because fresh silicic glass shards are widely disseminated although rare in Leg 90 sediments (Nelson, Froggatt, et al., this volume), it may be inferred that the PGLs are principally a record of basic to intermediate explosive volcanicity and that these more basic shards had very low preservation potential in the calcareous sediments during burial diagenesis.

\section{SEDIMENTATION RATES}

Figure 2 includes values for the average rates of sedimentation $(\mathrm{m} / \mathrm{m} . \mathrm{y}$.), uncorrected for sediment porosity, based on ages of nannoplankton zones (radiolarian/diatom zones at Site 594). Rates of sedimentation for pelagic carbonates range from as low as about $5 \mathrm{~m} / \mathrm{m}$.y. in the Paleogene of Site 593, to as high as $131 \mathrm{~m} / \mathrm{m}$.y. in the late early Pliocene of Site 591. Overall, sedimentation rates range between 15 and $30 \mathrm{~m} / \mathrm{m}$.y., although consistently higher rates of biogenic carbonate sedimentation are characteristic of certain times, especially in the late early Pliocene.

The physical property data for porosity and wet-bulk density of sediments enable calculations of mass accumulation rates (MAR) $\left(\mathrm{g} / \mathrm{cm}^{2}\right.$ per $10^{3} \mathrm{yr}$.). Because the $\mathrm{CaCO}_{3}$ content of most cores exceeds $95 \%$, changes in MAR largely represent changes in carbonate flux. Good intercore comparisons of accumulation rates for the $\mathrm{Ne}$ ogene at Leg 90 sites have been made (Fig. 3). The early Miocene (23-16 m.y.) has fairly constant MAR of about 2 to $3 \mathrm{~g} / \mathrm{cm}^{2}$ per $10^{3} \mathrm{yr}$., which began to fluctuate about 15 to 10 m.y. ago (middle Miocene). A major peak of up to $12 \mathrm{~g} / \mathrm{cm}^{2}$ per $10^{3} \mathrm{yr}$. is centered at $12 \mathrm{~m}$.y. The late Miocene (10 to 7 m.y.) section has fairly constant MAR of about $3 \mathrm{~g} / \mathrm{cm}^{2}$ per $10^{3} \mathrm{yr}$. In the latest Miocene, at about $6 \mathrm{~m}$.y., accumulation rates again increase to be- 
tween about 5 and $10 \mathrm{~g} / \mathrm{cm}^{2}$ per $10^{3} \mathrm{yr}$. and by the late early Pliocene ( 4 to $3 \mathrm{~m}$.y.) there is a remarkably widespread and brief peak of mass accumulation of up to 27 $\mathrm{g} / \mathrm{cm}^{2}$ per $10^{3} \mathrm{yr}$. Accumulation rates during the late Pliocene fall to much lower values, but are still consistently higher than average Neogene MAR. Except for Site 594, Quaternary MAR are generally much lower and are variable.

Apart from Site 594, the MAR probably reflect actual changes in calcareous biogenic productivity associated with fundamental paleoceanographic events that occurred during the Neogene in the southwest Pacific region (Kennett and von der Borch, this volume). The large MAR are not due to dilution from noncarbonate sources, because the noncarbonate materials occur in only minor amounts, and they do not reflect redeposition from winnowed areas, because there is little evidence of reworking of microfossils. The fast MAR are unlikely to be artefacts of an imprecise chronostratigraphy because the age boundaries have to be substantially changed to affect the pattern of increased MAR. The paleoceanographic reason for such high productivity in the late early Pliocene remains unclear. Relatively high MAR have also been reported elsewhere at this time, in the Colombia Basin, for example (Prell, Gardner, et al., 1982).

Sedimentation rates (both $\mathrm{m} / \mathrm{m}$.y. and MAR) in the north-south transect are generally highest throughout the Neogene at Site 586 on the equator and at Sites 590 and 591 at about $31^{\circ} \mathrm{S}$. The increased biogenic productivity probably relates to the location of these sites in nutrientenriched waters near major divergences, the Equatorial Divergence in the western Pacific and the Subtropical Divergence (or Tasman Front) crossing the central Tasman Sea (Fig. 1).

The relatively reduced rates of sedimentation (both $\mathrm{m} / \mathrm{m} . \mathrm{y}$. and MAR) in the Quaternary (and latest Pliocene) compared to the remainder of the Neogene at most sites in the Tasman Sea are due to increased winnowing by bottom currents at this time, related to stimulated circulation of Antarctic Intermediate Water, as evidenced by the overall coarsening of both bulk carbonate sediment and terrigenous sediment fractions at this time (Stein and Robert, this volume; Gardner, Dean, et al., this volume). Intervals of winnowed sediment are noticeably enriched in whole and fragmented foraminiferal tests, and interbedding of foraminifer and foraminiferbearing nannofossil oozes or of foraminifer-bearing and nannofossil oozes is common, correlated to the alternation of glacial and interglacial episodes, respectively (e.g., Nelson, Hendy, and Dudley, this volume). The unusually high MAR in the Quaternary at Site 587 (Fig. 3) are a result of downslope transport of coarse-grained, shallow-marine bioclastic carbonate from the Lansdowne Bank.

Sedimentation rates (both $\mathrm{m} / \mathrm{m} . \mathrm{y}$. and MAR) at subantarctic Site 594 are considerably higher (40 to $150 \mathrm{~m} /$ m.y. or 6 to $24 \mathrm{~g} / \mathrm{cm}^{2}$ per $10^{3} \mathrm{yr}$.) than at other Leg 90 sites. Lowest rates ( 30 to $40 \mathrm{~m} / \mathrm{m}$.y. or 2 to $6 \mathrm{~g} / \mathrm{cm}^{2}$ per $10^{3}$ yr.) occur in the latest Neogene, an interval interrupted by at least three disconformities. The high rates of sediment accumulation reflect (1) the proximity of Site 594 to South Island, New Zealand; (2) the generally high nutrient level of subantarctic waters near the Subtropical Convergence (Bradford, 1983), which probably developed during the middle Miocene (Kennett and von der Borch, this volume); and (3) the evidence (Site 594 chapter, this volume) for considerable amounts of local reworking and redeposition of older microfossils, certainly in the basal $150 \mathrm{~m}$ of section and to a lesser extent in the Quaternary interval of the core.

\section{BIOTURBATION}

Bioturbation is ubiquitous in Leg 90 sediments and has been reviewed by Nelson (this volume). Cores are dominated by a range of taxonomically nondiagnostic traces identified by subtle diagenetic color contrasts with the host sediment. These structures include abundant mottles, blebs, and spots, common streaks and wisps, and rare threads, tubes, rinds, halos, rings, and pockets. Some represent sections through Planolites and Trichichnus burrows. The trace fossils Planolites, Chondrites, and Zoophycos typically occur in association below a definite but variable sub-bottom depth at most sites.

The degree of bioturbation varies widely, both within and among sites. The principal controlling factors may be variations in bulk sediment flux and the flux of organic matter. Overall increases in these parameters during the Neogene can also explain the upward disappearance of the Planolites-Chondrites-Zoophycos association and its replacement by predominantly Planolites (-like) and nondiagnostic traces of indiscriminate burrowers. The timing of the changeover between the two burrowing assemblages varies from site to site (Nelson, this volume) and may be tied to the initiation and evolution of the various surface and intermediate water masses in the southwest Pacific region during the middle and late Cenozoic (Kennett and von der Borch, this volume).

\section{ASPECTS OF DIAGENESIS}

\section{Oxidized Versus Reduced Sediment}

Almost all the sites drilled on Leg 90 have a surficial oxidized zone of oozes directly resting on a thick reduced section of sediment. The oxidized zone is typically 30 to $60 \mathrm{~cm}$ thick, but reaches as much as 6 or $7 \mathrm{~m}$ at Sites 588 and 593, and is distinguished by its distinctive pale brown $(5 \mathrm{Y} 8 / 1,10 \mathrm{Y} 6 / 2)$, pale orange $(10 \mathrm{Y}$ $8 / 2,10$ YR $8 / 2,10$ Y $7 / 4)$, or yellow gray ( $5 Y 7 / 2$ ) color. Pyrite is absent in the oxidized zone, but the underlying reduced sediment contains disseminated fine-grained pyrite and is typically light gray (N7) to white (N9). The surface oxidized zone probably corresponds to a redox front that represents the level below which aerobic combustion of organic matter by microorganisms has depleted the available oxygen in the interstitial waters. Intensities of magnetization are relatively high (1 to $10 \mu \mathrm{G}$ ) within the oxidized zone, but they quickly drop to very low values $(<0.05 \mu \mathrm{G})$ in the anoxic sediments (Barton and Bloemendal, this volume), presumably as a consequence of the two-stage reduction of sulfates and iron oxides to pyrite (Karlin and Levi, 1983).

Site 593 is of particular interest because it also contains a distinctive, pale orange nannofossil ooze (Subunit IC) from about 394 to $418 \mathrm{~m}$ sub-bottom depth, in- 
terbedded with normal light gray to white nannofossil oozes of otherwise identical lithology (Fig. 2). The pale orange nannofossil ooze has relatively high intensities of magnetization. It formed between 15.5 and 15 m.y. ago and was not postdepositionally reduced, presumably because a change occurred in the balance between available dissolved oxygen supplied to the seafloor and available organic carbon supplied to the infauna, epifauna, and bacteria within the sediment. The subunit was deposited during a time of major ice buildup in Antarctica and it may be that the oxidizing event was associated with the brief development or intensification of an oceanographic front close to Site 593 that produced intermediate waters sufficiently oxygenated to prevent postdepositional reduction within the sediments. The thicker than normal (up to $6 \mathrm{~m}$ ) surficial oxidized zone at Site 593 may likewise reflect the present-day impingement of the northward flow of oxygen-charged Antarctic Intermediate Water on Challenger Plateau at about $1000 \mathrm{~m}$ water depth.

\section{Microfossil Preservation}

The qualitative assessment of downcore variations in the preservation of foraminiferal and calcareous nannoplankton microfossils included in Figure 2 is based on brief comments contained in the Biostratigraphy sections of the site reports (this volume). Preservation of the microfossils is generally very good in the thick sections of calcareous oozes; below them, it slowly deteriorates. Preservation in chalk ranges from moderately good to very poor. The relationship between degree of sediment lithification and microfossil quality is emphasized by the better preservation of shell material in oozes that persist below the ooze/chalk transition depth (e.g., Site 592). In addition, microfossil preservation significantly deteriorates in hard, recrystallized chalk sections at the bottom of several holes (e.g., Holes 590B, 591A, 592, and 594A). The recrystallized chalks include a large proportion of micritic carbonate particles, or micarb (Matter, 1974), which presumably represent disaggregated crystals freed by dissolution along element or segment sutures of small coccolith plates and foraminiferal fragments (Plates 1 and 2).

Preservation of the dominant calcareous nannofossil fraction varies systematically with depth. In general, discoasters, sphenoliths, and the rod-shaped genus Triquetrorhabdulus are the first to show secondary calcite overgrowths. In most Leg 90 sites, overgrowths begin in sections as young as the early Pliocene, probably because of the high mass accumulation rates of pelagic carbonate at this time (Fig. 3). Heavy overcalcification occurs from the middle Miocene downward, with discoasters showing fused rays and crystal faces, especially in the firmer nannofossil oozes and chalks (Plate 2). At this level the coccoliths also exhibit varying degress of secondary calcite overgrowths. In the Oligocene section of Sites 588 and 593, calcite overgrowths are prominent on all nannofossil species. In the middle Eocene section of Site 588 , the early Oligocene section of Site 592 , and the late Eocene section of Site 593, the preservation is good regardless of burial depth. In the first two cases the sed- iments include significant biosiliceous material and underlie the regional unconformity, and in the last a sequence of volcanogenic turbidites occurs immediately above the chalk containing the better-preserved calcareous nannoplankton, so that perhaps these local factors have somehow enhanced preservation.

\section{Authigenic Nodules}

Occasional nodules of chert and celestite $\left(\mathrm{SrSO}_{4}\right)$, up to $5 \mathrm{~cm}$ in size, were recovered at a few sites (Fig. 2). Biogenic silica has been dissolved in many Leg 90 sediments (Baker, this volume; Gardner, Nelson, et al., this volume) and forms the most obvious source of silica for local precipitation of opal-CT in chert nodules. The strontium for celestite formation is derived from the dissolution or recrystallization of biogenic calcite. Baker (this volume) shows that the concentration of dissolved $\mathrm{Sr}^{2+}$ in pore waters increases with depth at all sites and that as long as microbial sulfate reduction is relatively unimportant, celestite precipitation is possible.

Minor amounts of pyrite form ubiquitous, noncarbonate, authigenic mineral phases in Leg 90 sediments. Pyrite occurs as scattered framboids and micronodules, up to 1 to $2 \mathrm{~mm}$ across, commonly as small solid tubes 1 to $2 \mathrm{~mm}$ in diameter and several centimeters long, and rarely as larger nodules, sometimes in association with celestite. In many cases the pyrite is intimately associated with bioturbation structures (Nelson, this volume), suggesting precipitation of iron sulfide minerals within and about the preferred sites of sulfate reduction provided by the organic-matter-rich burrows.

\section{The Ooze/Chalk Transition}

The recovery of several continuous and largely undisturbed sections of pure carbonate sediments uncontaminated by significant quantities of biosiliceous and fine terrigenous material provides an excellent opportunity for the detailed study of the diagenetic processes that occur during the transformation of ooze into chalk (Plates 1 and 2). Some physical and chemical information relevant to the diagenesis of Leg 90 sediments is contained in the chapters by Baker (this volume) and Morin (this volume).

The general trend that pelagic carbonate sediments become increasingly lithified with greater depth of burial (e.g., Garrison, 1981) is well substantiated. Some relevant statistics are summarized in Table 3. The transition from soft to firm or stiff oozes ranges between 100 and $255 \mathrm{~m}$ sub-bottom depth. Generally, the further south the site is located, the deeper this transition occurs (Fig. 6). Also, at sites south of Site 590, the firmness of the oozes commonly varies below the first transition level, with variable-scale interbedding of soft and firm oozes.

At five sites (Sites 586, 588, and 590-592), the depth of the ooze/chalk transformation averages about $270 \mathrm{~m}$, with a total range of variation of only about $20 \mathrm{~m}$ (Fig. 6). The age of this transformation varies from about 8 m.y. at Sites 586 and 590 to almost 17 m.y. at Site 592, averaging $11 \mathrm{~m} . y$. over the same five sites. Sites 593 and 594 , the two southernmost sections, have oozes that persist to depths of 562 and $476 \mathrm{~m}$ respectively. Moreover, 
Table 3. Approximate sub-bottom depths and ages of the transition of soft to firm ooze and of firm ooze to chalk at Leg 90 sites.

\begin{tabular}{|c|c|c|c|c|c|c|c|c|}
\hline \multirow[b]{2}{*}{ Site } & \multirow{2}{*}{$\begin{array}{l}\text { Water } \\
\text { depth } \\
\text { (m) }\end{array}$} & \multirow{2}{*}{$\begin{array}{l}\text { Latitude } \\
\left({ }^{\circ} \mathrm{S}\right)\end{array}$} & \multirow{2}{*}{$\begin{array}{l}\text { Total core } \\
\text { penetration } \\
\text { (m) }\end{array}$} & \multicolumn{2}{|c|}{ Soft-firm ooze transition } & \multicolumn{2}{|c|}{ Ooze-chalk transition } & \multirow{2}{*}{$\begin{array}{l}\text { Avg. sedn. rate } \\
\text { for site }(m / m \text {.y. })\end{array}$} \\
\hline & & & & Depth (m) & $\sim$ Age (m.y.) & Depth (m) & $\sim$ Age (m.y.) & \\
\hline 586 & 2207 & 0.0 & 305.3 & 100 & 3.6 & 260 & 8.0 & 25 \\
\hline 587 & 1101 & 21.0 & 147.0 & $? 50$ & 3.5 & - & - & 21 \\
\hline 588 & 1533 & 26.0 & 488.1 & 165 & 8.0 & 245 & 13.0 & 17 \\
\hline 590 & 1299 & 31.0 & 499.1 & 200 & 6.0 & 269 & 8.0 & 25 \\
\hline 591 & 2131 & 31.5 & 500.4 & 175 & 4.0 & 290 & 9.0 & 29 \\
\hline 592 & 1098 & 36.5 & 388.5 & 205 & 12.0 & 273 & 17.0 & 16 \\
\hline 593 & 1068 & 40.5 & 571.5 & 205 & 9.0 & 562 & 40.0 & 14 \\
\hline 594 & 1204 & 45.5 & 639.5 & 255 & 10.0 & 476 & 13.0 & 46 \\
\hline
\end{tabular}

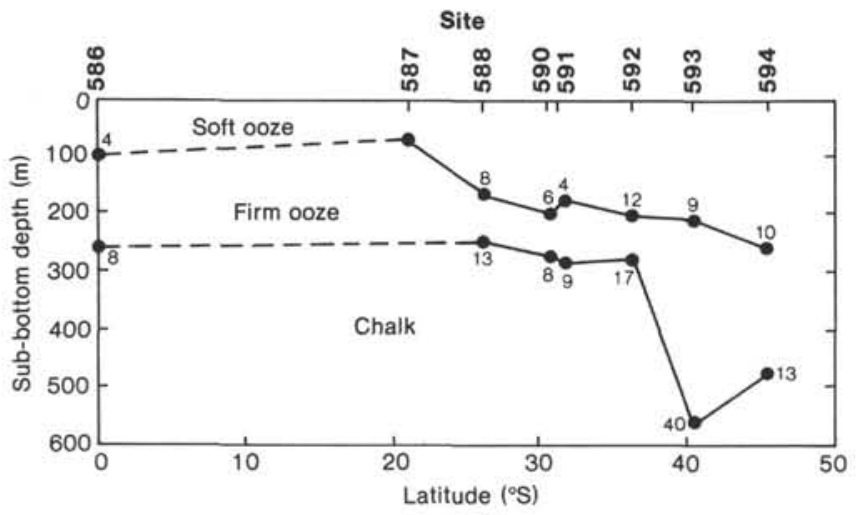

Figure 6. Changing sub-bottom depths with latitude of the transition level of soft to firm calcareous ooze and of firm ooze into chalk at Leg 90 sites. The numbers within the diagram are the approximate ages (in m.y.) of the transition depths at each site. Note the tendency for depths of transformation to increase with increasing southern latitude.

at Site 593 the age of the transition is as old as $40 \mathrm{~m} . \mathrm{y}$, but at Site 594 it is only 13 m.y.

Possibly delayed lithification may be related to the decreased content of discoasters and sphenoliths in the calcareous sediments at the southern sites. Both of these nannofossil groups, and especially the discoasters, provide ideal nucleation sites for calcite overgrowth and cementation during diagenesis (Schlanger and Douglas, 1974; Matter et al., 1975; Garrison, 1981). In Leg 90 sediments discoasters and sphenoliths are common only at warm-water sites; their low abundance and diversity at temperate Site 593 and subantarctic Site 594 (Fig. 7; Lohman, this volume) may be responsible for forestalling calcite crystallization in these sediments. In general it is anticipated that high-latitude pelagic carbonates will remain oozes to deeper burial depths than those in lower latitudes.

The same situation may also explain the reversal in the trend of increased lithification with burial depth that occurred at Site 592. Between about 305 and $360 \mathrm{~m}$ sub-bottom, early Oligocene soft to firm nannofossil ooze unconformably underlies early Miocene nannofossil chalk. The Oligocene ooze at the site is dominated by cold-water taxa with few discoasters and sphenoliths, so that calcite crystallization has been relatively inhibited. It is unlikely that this reversal in lithification is in any
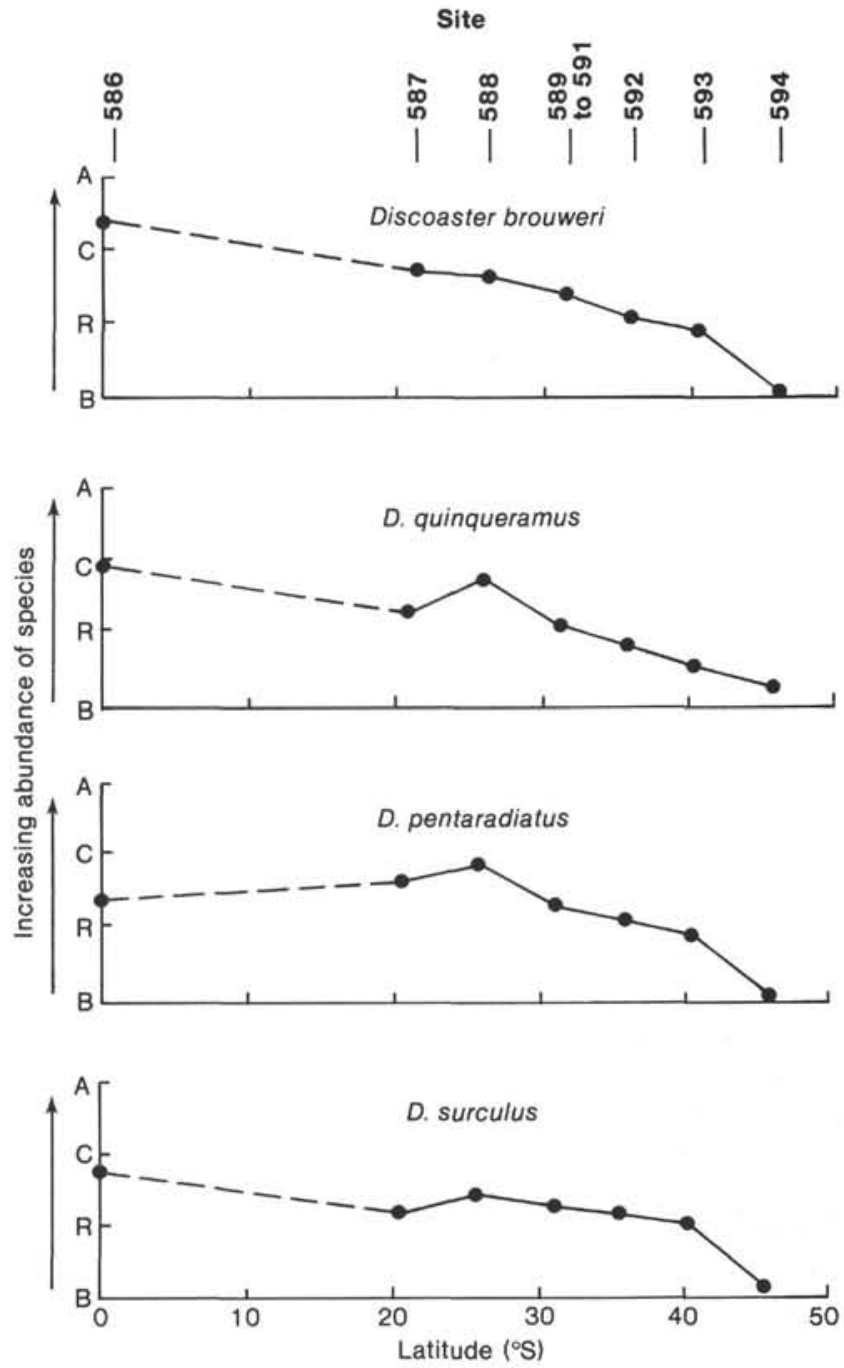

Figure 7. Examples of latitudinal abundance trends (A, abundant; C, common; R, rare; B, barren) for four important zone-defining species of discoasters in Leg 90 sediments (adapted from Lohman, this volume). Note the generally steady decline with higher latitude: the discoasters become extremely rare by $45^{\circ} \mathrm{S}$.

way associated with the regional unconformity (Packham and van der Lingen, 1973).

Burial lithification is reflected by the very gradual decline in sediment porosity with depth and the reciprocat- 
ing rise in bulk density (Morin, this volume). Porosities range from about 70 to $45 \%$ and are in the range of 50 to $53 \%$ at the depth where ooze becomes chalk. The transition is sudden and, across a very narrow porosity range of only 1 to $2 \%$, properties that relate to sediment rigidity, such as shear strength and compressional acoustic velocity, sharply increase.

Instances occur where porosity remains essentially constant over hundreds of meters of section, and there is no evidence of systematic compaction of the sediments although overburden stress substantially increases (e.g., Sites 590 and 593 from 200 to $450 \mathrm{~m}$ and 50 to $350 \mathrm{~m}$ sub-bottom depths, respectively). Among other reasons, Morin (this volume) suggests that this may be a consequence of locally very high sedimentation rates that, on the one hand, probably caused excess pore pressures that retarded initial compaction and promoted the formation of a competent sediment matrix and, on the other hand, increased the diagenetic potential of the carbonates (Schlanger and Douglas, 1974, p. 133), which accelerated point-to-point cementation between grains and increased sediment rigidity.

Apart from diagenetic color contrasts, associated commonly with organic traces, and the laminae of pale green altered tephras, the oozes and chalks are structurally almost homogeneous. However, below about 350,440 , and $550 \mathrm{~m}$ in the chalks at Sites 588, 591, and 594, respectively, flaserlike bedding occurs locally in the form of small elliptical nodules or "eyes" of purer chalk surrounded by wispy dissolution seams, relatively enriched in insoluble clay materials (Fig. 8). The flasers are associated with the progressive alteration of biogenic material in the recrystallized chalks and attest to more wholesale pressure-dissolution of carbonate sediment along horizons relatively enriched in terrigenous clays. Flasers are widely reported from many chalk sequences on land (e.g., Garrison and Kennedy, 1977). By about 600 m sub-bottom depth at Site 594, the flaser bedding is more pronounced and begins to resemble stylolite seams (Fig. 8).

In the early Miocene of Site 588 and the early late Miocene of Sites 590 and 591, short intervals of chalk are cut by suites of microfaults, some with slickensided surfaces. The faults are high-angle $\left(>60^{\circ}\right)$ and normal, with apparent dip-slip offsets of a few millimeters to centimeters. Sometimes the microfractures are healed by secondary minerals, including iron sulfides and possibly rhodochrosite. A tectonic origin is favored for these features, although some of the fractures may have been artificially produced by drilling.

\section{ACKNOWLEDGMENTS}

This review chapter could only be prepared by having access to much of the shipboard and shore-based lithologic data collected by my scientific colleagues on DSDP Leg 90 . Their major contribution in this regard is gratefully acknowledged. I particularly thank Jim Kennett and Jim Gardner for their helpful comments on a draft copy of the review.

\section{REFERENCES}

Berger, W. H., 1976. Biogenous deep-sea sediments: production, preservation, interpretation. In Riley, J. P., and Chester, R. (Eds.), Chemical Oceanography (Vol. 5): London (Academic Press), 265387.
Bradford, J. M., 1983. Plankton and primary productivity in the vicinity of the Chatham Rise. N.Z. Oceanogr. Inst. Oceanogr. Summary, 21:1-14.

Burns, R. E., Andrews, J. E., et al., 1973. Init. Repts. DSDP, 21: Washington (U.S. Govt. Printing Office).

Carter, R. M., and Carter, L., 1984. Tectonic and sedimentary controls on the evolution of the Bounty Channel, southwestern Pacific Basin. Geol. Soc. N.Z. Misc. Publ., 31A:34. (Abstract.)

Churkin, M., Jr., and Packham, G. H., 1973. Volcanic rocks and volcanic constituents in sediments, Leg 21, Deep Sea Drilling Project. In Burns, R. E., Andrews, J. E., et al., Init. Repts. DSDP, 21: Washington (U.S. Govt. Printing Office), 481-493.

Coleman, P. J., and Packham, G. H., 1976. The Melanesian borderlands and India-Pacific plates' boundary. Earth Sci. Rev., 12:197233.

Garrison, R. E., 1981. Diagenesis of ocean carbonate sediments: a review of the DSDP perspective. In Warme, J. E., Douglas, R. G., and Winterer, E. L. (Eds.), The Deep Sea Drilling Project: A Decade of Progress. Soc. Econ. Paleont. Mineral. Spec. Publ., 32: 181-207.

Garrison, R. E., and Kennedy, W. J., 1977. Origin of solution seams and flaser structure in Upper Cretaceous chalks of southern England. Sediment. Geol., 19:107-137.

Griggs, G. B., Carter, L., Kennett, J. P., and Carter, R. V., 1983. Late Quaternary marine stratigraphy southeast of New Zealand. Geol. Soc. Am. Bull., 94:791-797.

Imbrie, J., Shackleton, N. J., Pisias, N. G., Morley, J. J., Prell, W. L., Martinson, D. G., Hays, J. D., McIntyre, A., and Mix, A. C., 1985. The orbital theory of Pleistocene climate: support from a revised chronology of the marine $\delta^{18} \mathrm{O}$ record. In Imbrie, J., and Berger, A. (Eds.), Milankovitch and Climate Change: Amsterdam (Elsevier).

Jarrett, G. R., 1985. Late Cenozoic lithostratigraphy of DSDP Site 594, southwestern Chatham Rise, New Zealand, with emphasis on the paleoenvironmental significance of the late Quaternary sequence [M.Sc. thesis]. University of Waikato, Hamilton, New Zealand.

Karlin, R., and Levi, S., 1983. Diagenesis of magnetic minerals in Recent hemipelagic sediments. Nature, 303:327-330.

Kennett, J. P., Houtz, R. E., et al., 1975. Init. Repts. DSDP, 29: Washington (U.S. Govt. Printing Office).

Kennett, J. P., Houtz, R. E., Andrews, P. B., Edwards, A. R., Gostin, V. A., Hajós, M., Hampton, M., Jenkins, D. G., Margolis, S. V., Ovenshine, A. T., and Perch-Nielsen, K., 1975. Cenozoic paleoceanography in the southwest Pacific Ocean, Antarctic glaciation, and the development of the Circum-Antarctic Current. In Kennett, J. P., Houtz, R. E., et al., Init. Repts. DSDP, 29: Washington (U.S. Govt. Printing Office), 1155-1169.

Kennett, J. P., McBirney, A. R., and Thunell, R. C., 1977. Episodes of Cenozoic volcanism in the circum-Pacific region. J. Volc. Geothermal Res., 2:145-163.

Marchig, V., and Rösch, H., 1983. Formation of clay minerals during early diagenesis of a calcareous ooze. Sediment. Geol., 34:283-299.

Matter, A., 1974. Burial diagenesis of pelitic and carbonate deep-sea sediments from the Arabian Sea. In Whitmarsh, R. B., Weser, O. E., Ross, D. A., et al., Init. Repts. DSDP, 23: Washington (U.S. Govt. Printing Office), 421-470.

Matter, A., Douglas, R. G., and Perch-Nielsen, K., 1975. Fossil preservation, geochemistry, and diagenesis of pelagic carbonates from Shatsky Rise, northwest Pacific. In Larson, R. L., Moberly, R., et al., Init. Repts. DSDP, 32: Washington (U.S. Govt. Printing Office), 891-922.

Nelson, C. S., Hendy, C. H., Cuthbertson, A. M., Jarrett, G. R., and Black, K. P., 1984. A mid-late Quaternary isotope reference section for New Zealand: DSDP Site 594, eastern South Island. Geol. Soc. N.Z. Misc. Publ., 31A:88. (Abstract)

Nelson, C. S., and Hume, T. M., 1977. Relative intensity of tectonic events revealed by the Tertiary sedimentary record in the North Wanganui Basin and adjacent areas, New Zealand. N.Z. J. Geol. Geophys., 20:369-392.

Packham, G. H., and van der Lingen, G. J., 1973. Progressive carbonate diagenesis at Deep Sea Drilling Sites 206, 207, 208, and 210 in the southwest Pacific and its relationship to sediment physical properties and seismic reflectors. In Burns, R. E., Andrews, J. E., et al., Init. Repts. DSDP, 21: Washington (U.S. Govt. Printing Office), 495-521. 
Prell, W. L., Gardner, J. V., et al., 1982. Init. Repts. DSDP, 68: Washington (U.S. Govt. Printing Office).

Schlanger, S. O., and Douglas, R. G., 1974. The pelagic ooze-chalklimestone transition and its implications for marine stratigraphy. In Hsü, K. J., and Jenkyns, H. C. (Eds.), Pelagic Sediments: on Land and under the Sea. Int. Assoc. Sed. Spec. Publ., 1:117-148.

Seilacher, A., 1978. Use of trace fossil assemblages for recognizing depositional environments. In Basan, P. (Ed.), Trace Fossil Concepts. Soc. Econ. Paleontol. Mineral. Short Course, 5:167-181.

van der Lingen, G. J., Andrews, J. E., Burns, R. E., Churkin, M., Jr., Davies, T. A., Dumitrică, P., Edwards, A. R., Galehouse, J. S.,

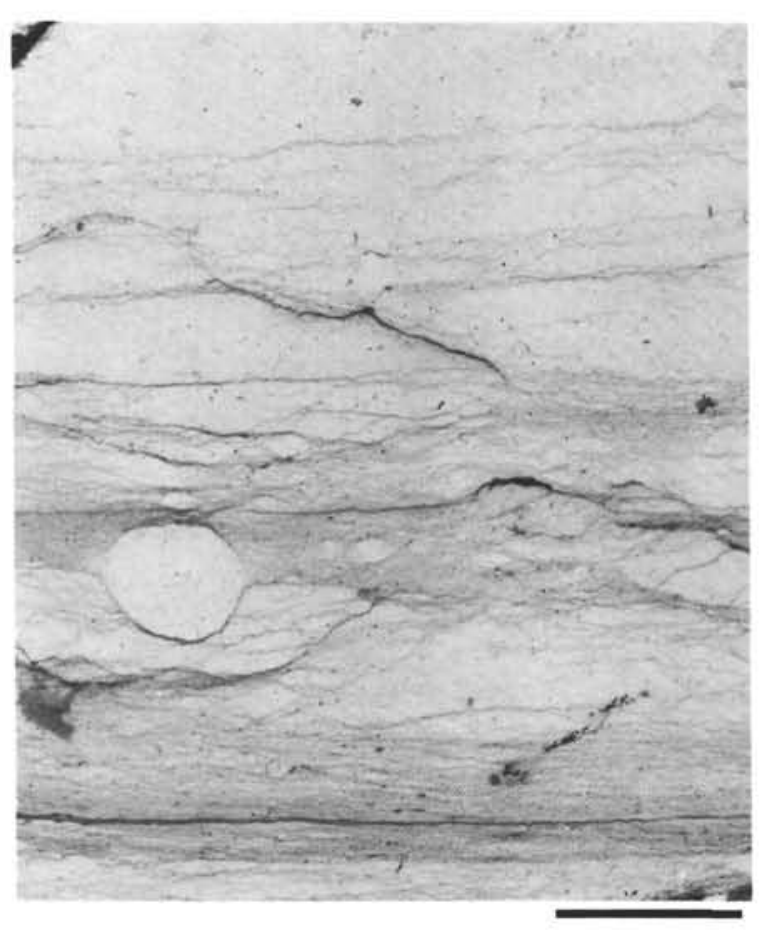

Date of Initial Receipt: 28 February 1985

Date of Acceptance: 6 June 1985

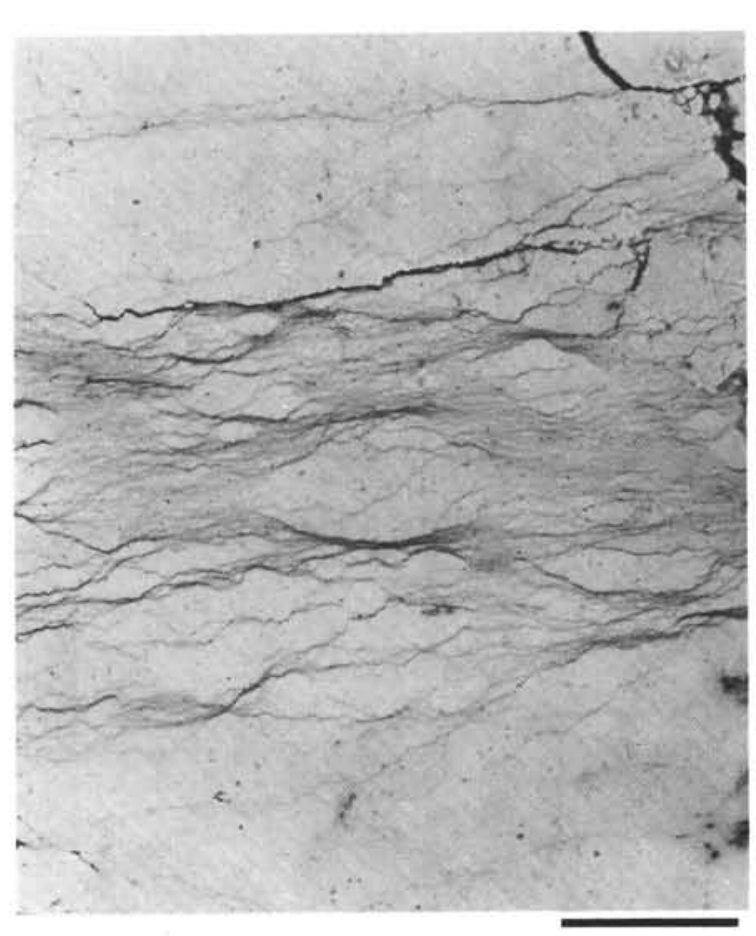

Figure 8. Examples of flaser structure and composite clay-rich dissolution seams in nannofossil chalks of late early Miocene age at about $630 \mathrm{~m}$ sub-bottom depth in Hole 594A off southeastern New Zealand. Bar scale $1 \mathrm{~cm}$.

Kennett, J. P., and Packham, G. H., 1973. Lithostratigraphy of eight drill sites in the South-west Pacific-preliminary results of Leg 21 of the Deep Sea Drilling Project. In Fraser, R. (Ed.), Oceanography of the South Pacific 1972: Wellington (N.Z. National Commission for UNESCO), pp. 299-313. 

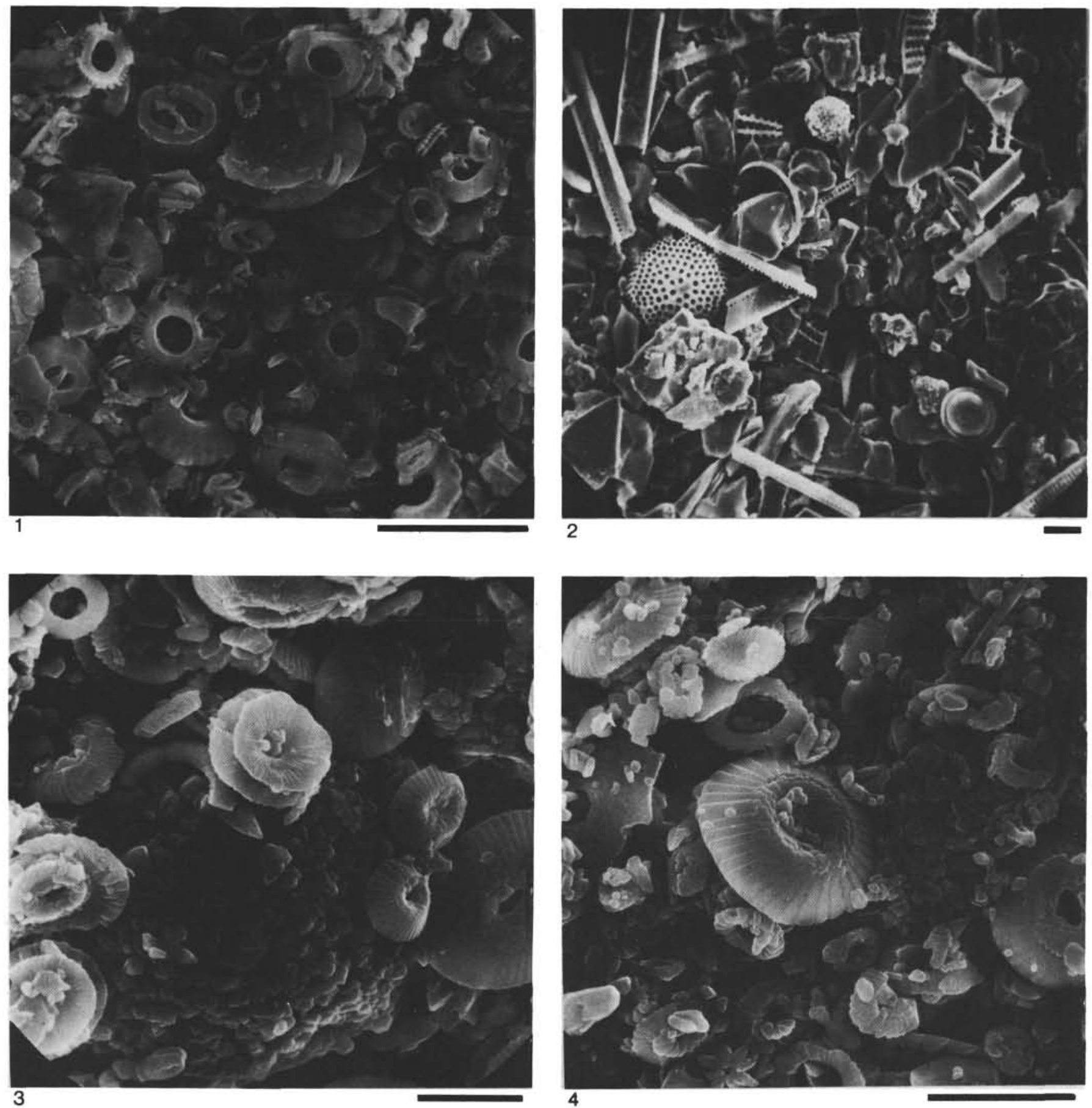

Plate 1. Scanning electron micrographs of fracture surfaces of Leg 90 oozes, in order of increasing burial depth. Bar scale $5 \mu \mathrm{m}$. 1. Soft nannofossil ooze dominated by whole and broken coccolith shields, some exhibiting peripheral dissolution; Sample 588-2-4, 70 cm, early Quaternary; burial depth $10.80 \mathrm{~m}$. 2. Soft hemipelagic ooze of biosiliceous-material-bearing clayey silt; terrigenous matter is dominated by quartz and mica, and siliceous microfossils include diatoms, sponge spicules, and radiolarians; Sample 594-9-4, $80 \mathrm{~cm}$, late Quaternary; burial depth $78.41 \mathrm{~m}$. 3. Soft foraminifer-bearing nannofossil ooze showing well-preserved whole and some broken coccolith shields and a portion of a foraminifer wall with evidence of strong dissolution; calcite crystals freed in this manner are probably an important source of micarb particles; Sample 592-11-3, $141 \mathrm{~cm}$, early Pliocene; burial depth $95.32 \mathrm{~m}$. 4. Stiff nannofossil ooze comprising coccolith shields, some showing marginal corrosion and dissolution of central structures, a slightly calcite-overgrown sphenolith (bottom left), and abundant micarb particles; Sample 591-30-2, 140 cm, late Miocene; burial depth $272.21 \mathrm{~m}$. 

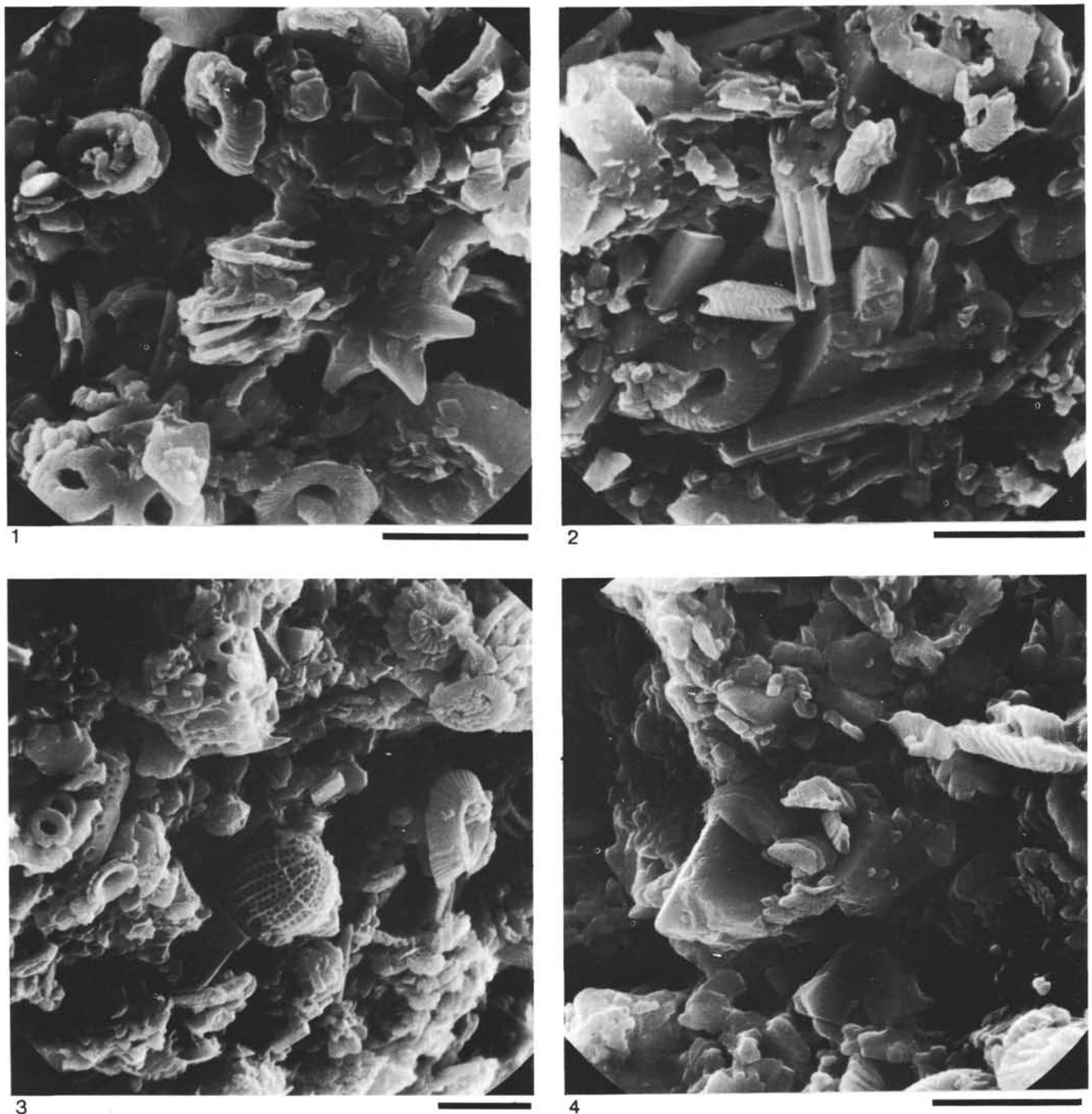

Plate 2. Scanning electron micrographs of fracture surfaces of Leg 90 chalks, in order of increasing burial depth. Bar scale $5 \mu \mathrm{m}$. 1. Nannofossil chalk showing selective fusion of portions of the nannoplankton elements as a result of calcite overgrowth about the discoaster and between several coccolith shields; Sample 588A-9-3, $30 \mathrm{~cm}$, middle Miocene; burial depth $283.90 \mathrm{~m}$. 2. Nannofossil chalk showing fusion and overgrowth of several nannoplankton elements and a moderately advanced stage of pore plugging by large crystals of rhombic calcite cement; Sample 588C$14-4,77 \mathrm{~cm}$, late Oligocene; burial depth $435.79 \mathrm{~m}$. 3. Biosiliceous-material-bearing nannofossil chalk showing both corroded and overgrown coccoliths and some radiolarian and diatom material differentially cemented by microgranular calcite; Sample $588 \mathrm{C}-19-1,49 \mathrm{~cm}$, middle Eocene; burial depth $479.00 \mathrm{~m}$. 4. Very hard nannofossil chalk in which extensive calcite cement overgrowths about discoasters in particular have poikilitically enclosed surrounding nannofossil and micarb material; Sample 591B-24-4, $136 \mathrm{~cm}$, early Miocene; burial depth $496.67 \mathrm{~m}$. 